\title{
Para u ma Teorização da Metáfora para a Análise e Interpretação Musical
}

\author{
Towards a Theorisation of the Metaphor for Analysis \\ and Musical Performance
}

\section{Ana Cristina Bernardo}

Escola de Música do Conservatório Nacional, Portugal

anacristinab@sapo.pt

\section{Eduardo Lopes}

Universidade de Évora, Portugal

el@uevora.pt

Resumo: Este artigo aborda o uso da metáfora como uma prática recorrente do pensar e fazer musical. Estando presente como recurso desde os primórdios da reflexão e exposição oral sobre música, a metáfora tornou-se cada vez mais embebida em todos os fazeres musicais. Com as constantes aberturas estilísticas que a música ocidental tem sofrido desde o último quartel do século XX, pensa-se cada vez mais na metáfora como ferramenta privilegiada para a realização musical. Para uma consciente teorização da metáfora musical, apresentam-se dois estudos de caso em que a metáfora serve de eficiente fio condutor que parte desde a composição, passa pela análise, e imagina-se uma interpretação.

Palavras-chave: Metáfora; Teoria Musical; Análise Musical; Interpretação.

\begin{abstract}
This article tackles the use of metaphors as a recurring practice for thinking and doing music. Used as tool since the early days of the overall music making processes and experience, metaphors have become embedded in music itself. With the genre widening in western music that has been happening since the late decades of the XX century, metaphors are privileged tools for musical realisation. Towards a theorisation of the musical metaphor, this article presents two case studies in which metaphors are presented as an efficient way to link compositional thought, analysis, and performance decisions.
\end{abstract}

Keywords: Metaphor; Music Theory; Music Analysis; Performance. 


\title{
1. A Génese de um Novo Pensamento
}

Cerca de 1960, a maioria dos jovens compositores ligados ao serialismo e à música aleatória encontraram caminhos composicionais alternativos, num alinhamento criativo que abrangeu uma extensa gama estilística. Assim se constituiu a génese de um período muito profícuo na experimentação musical, que se inspira e acompanha as outras manifestações da criação artística, caracterizada pela multiplicidade de abordagens diversificadas.

Do ponto de vista sociológico, a década de 60 testemunhou uma forte reação do mundo ocidental contra os governos centralizados e outras formas de imposição; cultivaram-se formas de vida alternativas, e o conceito de arte expandiu-se, ampliando a gama das escolhas culturais. Tendo a atitude vigente sido a de distanciação para com o contexto social, muitos compositores conceptualizaram a música como uma atividade que interage com a vida corrente. A preocupação sobre questões como a interação de grupos, instituições sociais e o ambiente, chamam estes compositores a intervir numa dimensão política. $\mathrm{O}$ aprofundamento da consciência política, tem raízes nas revoluções culturais dos anos 60, onde fortes sentimentos de insatisfação encorajaram o uso da música e das artes em geral, veiculando a interação e mudança social. A politização da música demonstrou a sua natureza revolucionária, inicialmente através de questões ligadas à linguagem que assumiram posteriormente um papel social e que são demonstrativas da implementação de uma mentalidade democrática nos meios da atividade criativa musical.

Bernardo (2014, p. 26) afirma:

\begin{abstract}
Muitos compositores que encontraram formas de expressão mais personalizada, no ensejo de cortar com as restrições extremas do serialismo, adotam ideias de negação da universalidade e muitas vezes da assumida coerência da sua produção musical. O conceito tradicional de obra de arte autónoma e destinada a uma audiência passiva foi seriamente comprometido: deixa de existir a aspiração à imortalidade. A atmosfera de abertura encorajou a investigação e abordagens inovadoras da composição, refrescando a energia criativa dos compositores que se conduzem por regiões inexploradas no passado.
\end{abstract}

Com a perceção do esvaziamento do vanguardismo a partir dos anos 60 os compositores repensam a questão da expressividade: ao rejeitarem a necessidade de originalidade e de elitismo intelectual dos modernistas, os criadores enveredam por perspetivas mais tradicionalistas. As ligações com o passado tornam-se terreno fértil e adotam-se estratégias harmónicas e temporais relacionadas com séculos anteriores.

Marcado por uma pluralidade de opções, o pós-modernismo conhece ainda outra possibilidade de ser incorporado: a inclusão eclética de discursos 
diversos através da citação ou colagem. Gloag (2012, p. 55) menciona como exemplo destes processos de interceção entre passado e presente a Sinfonia de Luciano Berio, e a forma intertextual como esta tem sido discutida e analisada numa perspetiva pós-moderna.

A ética do pós-modernismo implica uma aceitação da diferença e da ironia, pela sobreposição de elementos contrastantes: original com empréstimo; erudito com popular; recente e antigo; entre outros numerosos elementos, como aponta Toop (2004, p. 461) referindo a dimensão "hiper-expressiva" em certas peças de Ligeti. Todos estes elementos que se cruzam nesta nova estética encontram raízes ao longo do decorrer da história da música ocidental; o movimento inicial do pós-modernismo na música situa-se nos anos 70, mas encontra as suas raízes espalhadas em várias estéticas, pelo que se torna impossível ser encarado como um movimento rigidamente demarcado numa cronologia.

A obra musical abandonou o seu papel de entidade autónoma para permitir novas inserções estilísticas, incluindo outros géneros musicais, em que a música folk, pop, jazz, e rock demonstraram ser terreno fértil para estas novas explorações. A interação entre a música folk, pop e jazz e a música erudita está fortemente representada no século XX: Igor Stravinsky, Eric Satie e Kürt Weill demonstram uma imensa influência da música popular, enquanto no jazz temos presenças como Claude Debussy, Igor Stravinsky, Paul Hindemith e Maurice Ravel.

Até 1960, muitos compositores procuram uma linguagem musical distanciada da tonalidade. No entanto, o estilo considerado contemporâneo é desvanecido pela aceitação do diatonismo dos minimalistas. Também, a generalização do recurso a citações tonais e as alusões ao rock, pop e jazz, retiraram evidência ao estilo puramente contemporâneo. A acessibilidade a uma gama extensa de influências posiciona assim a música num evento estilisticamente mais aberto. Este ecletismo veio então a encorajar a reconsideração da tonalidade como um retorno consciente a um recurso possível.

Dentro deste paradigma desenvolveu-se uma gama de subculturas que interagem e se influenciam mutuamente, mas que se mantêm independentes: cada uma das subculturas tem a sua audiência e os seus sistemas de divulgação, numa coexistência pacífica e sem consenso. Sinais de um novo a mbiente es tético são a criação de grupos especializados em performance que se dedicam a uma imensidão de perspetivas musicais, desde a música antiga, avant-garde, música exótica, pop e folk. O passado musical encontra-se entre nós confrontado com o presente, e a mbos coexistem numa mistura eclética que se espelha na vida musical. Este conjunto de circunstâncias necessitará de uma re definição do conceito de cultura musical: os compositores levados pela cultura global, e sem limites de es paço e tempo, muda m de orientações muito rapidamente, cuja consequência imediata é a redefinição do conceito de estilo. Vários compositores defendem a sua posição estética: encaram o estilo como uma forma temporária de escolher e combinar elementos heterogéneos. Esta postura propositadamente eclética torna-se confortável para os criadores oriundos de diversas vertentes que se têm envolvido com a música erudita. (Bernardo, 2014, p. 55).

\section{MUSICA THEORICA}


A diversidade de opções composicionais e performativas, assumida criativamente pelo artista que se afasta da necessidade do enquadramento da sua produção em determinado movimento estético estilístico, conduz a postura analítica a uma adaptação, recorrendo a abordagens múltiplas que dependem da perspetiva e do enquadramento versando o objeto de estudo.

Como Pinho Vargas (2008, p. 183) consubstancia:

Os anos 80 confirmaram o fim das direcções únicas. A própria noção de vanguarda (...) está posta em causa. A característica principal das estéticas contemporâneas em todas as artes é a existência de uma pluralidade de direcções simultâneas. Não há certezas, há problemáticas.

\section{Conceptualizando a Metáfora}

Numa perspetiva de análise para a interpretação, alguns elementos relacionados com a conceção analítica do intérprete urgem como pontos a esclarecer. Não pode ser relevado para segundo plano o facto de a focalização temática do estudo a desenvolver residir na música composta na atualidade, não descurando os pressupostos do ecletismo e da pluralidade aceites como verdades criativas. $\mathrm{O}$ pós-modernismo levanta assim questões fulcrais para $\mathrm{o}$ esclarecimento da atividade musical, neste caso, englobadas num âmbito analítico e interpretativo. Samson (2010, p. 53) comenta a necessidade da teoria e análise dos dias de hoje integrarem questões de contexto, performance e perceção nas suas conceptualizações e discursos.

Korsyn (2010, p. 59) expõe a problemática da análise da atualidade, estabelecendo um paralelo com modelos e procedimentos da crítica e história da literatura. Sobre este assunto, citando o musicólogo Peter McCallum, Korsyn refere que uma das falhas da análise do passado é a forma pouco sofisticada e por vezes inapta como aborda "articulações de terceira ordem"; como por exemplo: o gesto musical, referências estilísticas, e até ironia.

Torna-se fulcral ter presente a evidência de que quando é executada uma obra de J. S. Bach ou W. A. Mozart já o intérprete tem integrado um imenso património linguístico e cultural a suportar as decisões interpretativas, para não falar da experiência adquirida pela prática diária do seu instrumento. Sobre esta dificuldade dos intérpretes enveredarem pela exploração de obras com conteúdos semióticos ainda pouco assimilados no seu património interpretativo, será elucidativo o testemunho do pianista e musicólogo Charles Rosen (2002, p. 226-227) ao referir as grandes dificuldades na aprendizagem de três peças curtas de Milton Babbitt e a assimilação dos seus códigos específicos, devido ao tempo despendido até conhecer a sua linguagem.

Perante a problemática da diversidade estilística já referenciada, formula-se a hipótese de que o pensamento metafórico é um elemento 
primordial para a construção da narrativa interpretativa, elemento este desvanecedor da primazia concedida ao código a decifrar, contido na partitura, e exponenciador dos objetivos do intérprete. Esta premissa é reforçada pelo facto de que as peças a analisar contém uma componente metafórica explicitada. Torna-se essencial definir a questão da metáfora e seu impacto na interpretação. Dortier (2006, p. 467-468) desenvolve este conceito:

O termo "metáfora" provém do grego metaphora, que significa "transporte". Em A Poética, Aristóteles define-a assim: "A metáfora é o transporte para uma coisa de um nome que designa uma outra". (...) A metáfora permite sublinhar traços salientes de uma pessoa ou de um comportamento. Possui ao mesmo tempo uma grande força argumentativa e um poder heurístico, pois permite "fazer compreender", por analogia, sem ter de descrever nem explicar. (...)

A metáfora permite pôr em ligação coisas distintas sublinhando os seus pontos de semelhança. Considerada durante muito tempo uma simples figura de estilo, a metáfora poderia ser um processo fundamental do conhecimento. Esta é a tese defendida por alguns linguistas, especialistas de ciências cognitivas e teóricos da literatura, como George Lakoff, Mark Johnson ou Mark Turner. Na medida em que permite "fazer adivinhar" certas coisas através de exemplos, de imagens deslocadas, de analogias, a metáfora é um poderoso instrumento para revelar as estruturas comuns, configurações semelhantes, traços idênticos entre duas coisas distintas.

Trata-se então da criação de analogias, pontos de ligação entre ideias e estruturas. Lakoff e Johnson elaboraram uma teoria sobre a metáfora, afastando-se da ideia interligada com os aspetos formais da linguagem e introduzindo um conceito da metáfora como uma forma de pensamento. A sua teoria baseia-se numa ligação entre a vivência física e os conceitos abstratos. Mas esta teoria não determina só a ligação entre os conceitos básicos e a organização espacial destes mesmo, avançando para uma ideia de que a estruturação metafórica se constrói dentro de um âmbito de uma coerência cultural proveniente da sociedade em que cada indivíduo está inserido. Lakoff e Johnson (2003, p. 146) defendem que a realidade para um indivíduo inserido numa determinada cultura depende de dois fatores: a sua realidade social e a forma como este a experiência em termos físicos. Os autores defendem ainda que como a realidade de cada indivíduo é apreendida em termos metafóricos, e como a própria perceção corporal é em parte também metafórica, a metáfora torna-se um elemento nuclear na determinação do estabelecimento da realidade desse mesmo indivíduo.

Sob a perspetiva do intérprete interessa focalizar em que sentido o pensamento metafórico constitui um pressuposto performativo, uma vez que torna fundamental a criação do significado no ato de interpretar. Pensando que a atividade do intérprete depende de dois elos primordiais, balançados entre a perspetiva racional e a imaginação, será de antever que Lakoff e Johnson (2003, 
p. 192-193) determinam a metáfora como o elemento potenciador da unificação da razão e da imaginação.

Este equilíbrio entre a razão e a imaginação constitui uma base interessante para a determinação do ato performativo, sendo então o recurso ao pensamento metafórico uma plataforma determinante para a construção de uma narrativa de cunho pessoal. Numa perspetiva do estabelecimento da analogia entre a música e o pensamento metafórico, Zbikwoski (2009, p. 376), um investigador que se debruça sobre os aspetos cognitivos da música, assinala algumas diferenças entre a utilização da metáfora na linguagem e na música, e introduz o conceito de "metáfora multimodal": uma forma de representar simbolicamente objetos e relações (do âmbito musical), dirigindo a atenção de terceiros para imagens com referenciais comuns.

\section{Análise para a Interpretação}

Constituindo-se como estudo de caso, as duas peças escolhidas serão analisadas tendo em conta o conteúdo da mensagem encontrada no texto das canções originais provenientes do cancioneiro popular português, propondo-se um pressuposto analítico de compreensão entre a analogia sonora e o ponto de partida de cada canção. Este estudo analítico basear-se-á na interligação das simbologias provenientes das fontes escritas, passando pelas simbologias criadas pelo compositor (patentes nas notas de programa e na partitura) e pela construção da imagética interpretativa; trata-se, no entanto, da construção de uma narrativa interpretativa de cariz pessoal.

Espelho da Alma é uma obra composta em 2009 por Eurico Carrapatoso, destinada à formação instrumental de quarteto de cordas com piano, encomendada pelo Ensemble Darcos e dedicada ao compositor Nuno CôrteReal. Carrapatoso atribuiu a Espelho da Alma o subtítulo Subsídios para o estudo de uma orografia musical portuguesa, e as sete peças que a constituem são intituladas respetivamente: Eterno, Pírrico, Sedoso, Careto, Saudoso, Pícaro e Materno. A obra em questão constitui-se num conjunto de harmonizações, fonte de inspiração recorrente neste compositor (Carrapatoso 2009, p. 5).

Trata-se de identidade. Trata-se de alma, portanto. Trata-se de tudo o que é essencial, apresentado à guisa de um políptico disposto num retábulo simetrizante, como se de um espelho se tratasse. E, tal como as imagens projectadas num espelho, revelam-se não apenas os sentidos mais escondidos, aqueles que se representam em baixo-relevo, bem como o alto-relevo dos costumes, a cordilheira dos afectos, o barómetro das emoções, a orografia dos sentimentos. Sim: a alma é a orografia da vida, com os seus picos e as suas depressões. A alma é essa elipse que vai do Eterno ao Materno, do Pírrico ao Pícaro, do Sedoso ao Saudoso, ancorada nesse eixo bicéfalo que é o Careto, a máscara, a projeção de nós próprios nas pulsões mais cruas, mais instintivas,

\section{MUSICA THEORICA}


nessas pulsões que o grande Francis Bacon (1909-1992) tanto e tão bem decantou na sua pintura.

Todas elas são baseadas em melodias tradicionais portuguesas e nas notas de programa, Carrapatoso (2009, p. 6) explica a proveniência de cada canção, assinalando-se as canções Pírrico e Pícaro:

2. Pírrico - Mirandum se Fui a la Guerra (região mirandesa, Trás-os-Montes), n'O Cancioneiro Popular Português de Michel Giacometti1

6. Pícaro - Mira-me Miguel (região mirandesa, Trás-os-Montes), recolhido no

CD Songs and dances of Portugal de Michel Giacometti

Carrapatoso estabelece uma ligação semântica de uma construção em espelho e de um retrato das suas raízes culturais, logo lançada no título da obra e definidora de toda a sua estrutura, como se pode observar na Figura 1.

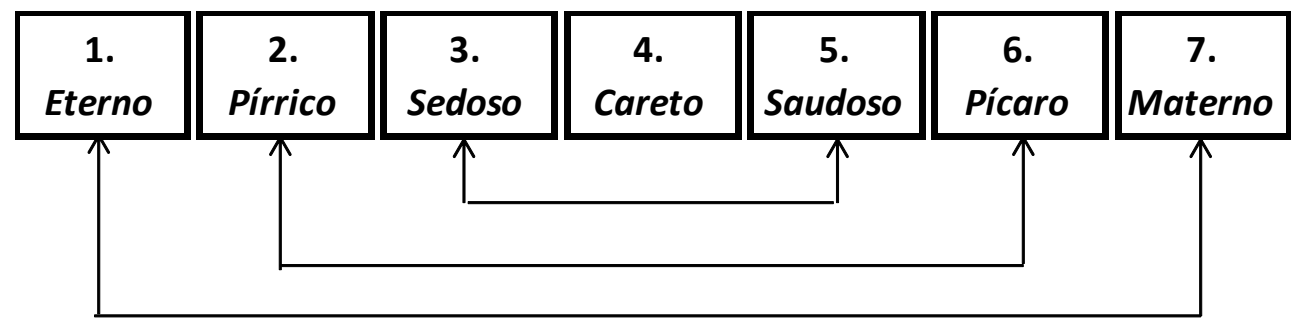

Figura 1: correspondência entre as peças

\subsection{Pírrico - Mirandum se Fui a la Guerra}

Comparativamente ao registo da canção realizado por Giacometti, existem algumas alterações nas sucessões frásicas a assinalar; no entanto, embora Pírrico não contenha todo o trajeto delineado em Mirandum se fui à la guerra, são mantidas as características melódicas que permitem aos executantes e ouvintes reconhecer de imediato a sua origem. Entendendo a estruturação melódica da canção realizada por células de dois compassos, e atribuindo a cada célula uma letra $(a, b, c, d)$, a organização das frases encontra-se exposta na Figura 2.

${ }^{1}$ Giacometti, Michel Marie (...) Colector de nacionalidade francesa, radicado em Portugal. Foi um dos colectores de maior relevo a nível nacional. (...) Palmilhou o país, procedendo a registos sonoros. Nos anos iniciais acompanhou Fernando Lopes-Graça (idas à Beira Baixa), depois manteve com este compositor uma relação de complementaridade pós-terreno. (Branco 2010, p. 564) 


\begin{tabular}{|c|c|c|c|c|}
\hline $\begin{array}{c}\text { Mirandum } \\
3 \text { estrofes }\end{array}$ & & $a \mathrm{a} \mathrm{b} c$ & $d d^{b} d^{\prime}$ & \\
\hline \multirow{3}{*}{ Pírrico } & $\begin{array}{l}\text { 1a secção } \\
\text { (cc. } 1 \text { a 26) }\end{array}$ & $a \mathrm{a} b \mathrm{~b}$ & $a \mathrm{a} b \mathrm{~b}$ & $c d c^{\prime}$ \\
\hline & $\begin{array}{c}\text { 2a secção } \\
\text { (cc. } 27 \text { a 53) }\end{array}$ & $a \mathrm{ab} b$ & $a \mathrm{a} b \mathrm{~b}$ & $a \mathrm{ab} b$ \\
\hline & $\begin{array}{c}\text { 3a secção } \\
\text { (cc. } 54 \text { a 75) }\end{array}$ & $a \mathrm{ab} b$ & $a \quad b \quad b c^{\prime \prime}$ & \\
\hline
\end{tabular}

Figura 2: disposição das células melódicas

A peça está dividida em três secções, que são sempre introduzidas pelo piano, mantendo uma ideia de que cada estrofe corresponde a uma secção, com algumas variações nos recursos composicionais. Na $1^{\text {a }}$ secção, o violino é o protagonista, ou seja, o detentor da melodia principal, o violoncelo e a viola executam pequenos arpejos, e o piano acompanha. No c. 13, a viola inicia uma segunda voz, tornando a textura mais densa. No c. 20, a viola e o violoncelo reforçam o violino com vozes diferentes e o piano abandona a célula rítmica caracterizante desta peça, referenciada no Exemplo 4, para colaborar numa escrita verticalizada. $\mathrm{Na} 2^{\underline{a}}$ secção o piano executa a melodia; também em cada repetição da melodia se dá um adensar da textura, desta vez no piano, cuja mão direita irá fazer duas vozes e, no caso da mão esquerda com a realização de acordes de 9 $^{\underline{a}}$ (com a sobreposição das $5^{\frac{a}{a}}$ s auditivamente muito expostas). $\mathrm{O}$ violoncelo torna-se um elemento coadjuvante no reforço desta textura. A $3^{\text {a }}$ secção constitui um retomar da $1^{\text {à }}$ secção, com o violino uma $8^{\underline{a}}$ acima (c. 57), retomando a tessitura inicial no c. 66. A pequena Coda final (cc. 73 a 75), mais lenta, evoca o correspondente ao final da $1^{\underline{a}}$ secção.

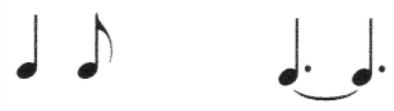

Exemplo 1: células rítmicas da $1^{\underline{a}}, 3^{\underline{a}}$ e $2^{\underline{a}}$ secções

O caráter rítmico desta peça sobressai no piano, através de uma célula rítmica afirmada constantemente na $1^{\underline{a}}$ e $3^{\underline{a}}$ secções, e é menos irrequieto na $2^{\underline{a}}$ secção através da sua distensão para uma relação de valores com dois tempos (Exemplo 1). Esta alteração rítmica é um elemento determinante na estrutura da peça, conferindo-lhe um balanço caracterizante revelado na métrica dos acordes do piano que se encontra sincopada. O pianista é responsável pela sustentação da coesão de todo o grupo através destes ostinatos, pois ao manter uma atitude 
rítmica inabalável constitui-se como elemento de referência. Sendo o compasso da canção de origem mantido em Pírrico, o 6/8, Carrapatoso introduz uma escrita de $3 / 4$ no violoncelo entre os cc. 13 a 21 e cc. 30 a 36, no violino entre os cc. 38 a 44, e novamente no violoncelo entre os cc. 66 a 73. Especialmente nestes casos de sobreposição da métrica, o ostinato do piano funciona como um sustentáculo do grupo na perspetiva fulcral de manutenção da pulsação.

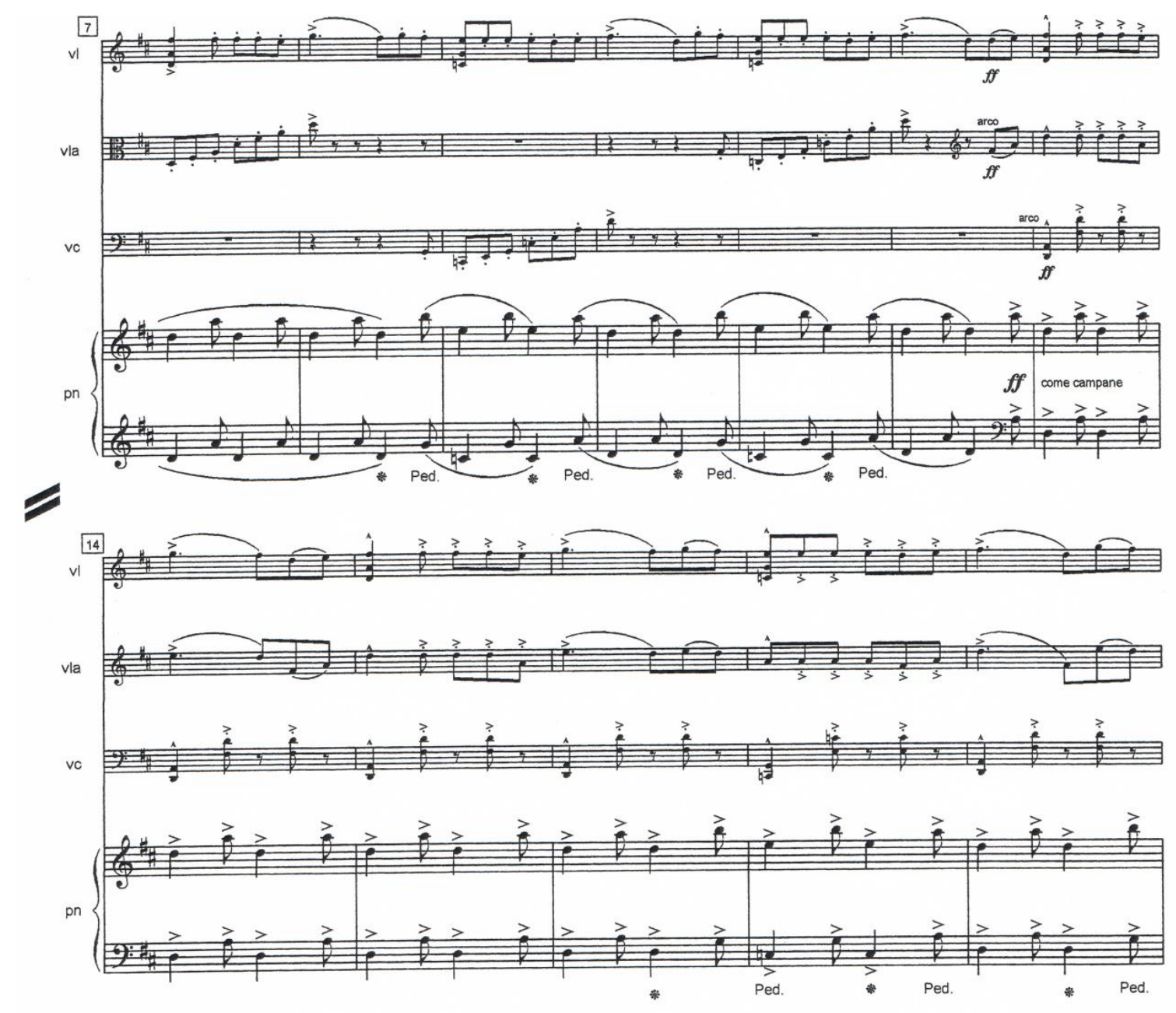

Exemplo 2: compassos sobrepostos

A sobreposição rítmica, expressa no Exemplo 2, deve constituir objeto de troca de ideias entre os elementos do quarteto e pode induzir uma imagem interpretativa da dança guerreira, evocada no título da peça, onde as figuras rítmicas do compasso 3/4 simbolizam o manuseamento das armas que os homens empunhavam, sendo então esta passagem executada dentro de um ambiente sonoro muito vigoroso. A indução imagética é mencionada por Carrapatoso (2009, p. 7): 
(...) esta dança guerreira (ou dança pírrica, que era a dança masculina feita com armas na mão, na qual os homens se exercitavam desde cedo), é originária da Guerra do Mirandum (episódio da Guerra dos Sete Anos, com o cerco de Miranda do Douro feito pelos espanhóis em 1762) (...).

Em termos de comunicação entre os elementos do quarteto, a frase final requer alguma reflexão e apela à comunicação gestual entre os intérpretes: partindo de uma mudança para um andamento muito mais lento, impõe-se uma atitude assertiva uma vez que entre o violoncelo e o piano existe uma rítmica baseada em agrupamentos de duas colcheias, inicialmente prosseguida pelo violino e a viola, mas que posteriormente passa a uma organização de três colcheias. Esta escrita converge novamente para o recurso à sobreposição de compassos, onde desta vez o compasso de $3 / 4$ se encontra no piano e no violoncelo.

A recolha da canção Mirandum se fui a la guerra foi registada no modo mixolídio, em Fá; neste caso, encontra-se assinalada pelo compositor a tonalidade de Ré, contendo, no entanto, maioritariamente o VII grau descido meio-tom. As suas características modais são reforçadas com o recurso ao intervalo de $5^{\text {a }}$ nas vozes de acompanhamento, como nos cc. 21 a 25 na mão esquerda do piano, nos cc. 30 a 37 na viola e de uma forma arpejada no violino (formando um arpejo de $9^{\mathrm{a}}$ ). A harmonia com acorde de $7^{\mathrm{a}}$ com função de subtónica confirma constantemente a modalidade logo expressa nos arpejos do violoncelo (c. 9) e violino (c. 11), com a cumplicidade da mão esquerda do piano a realizar um intervalo de $5^{\text {a }}$ também com subtónica (Dó - Sol). O piano mantém um ostinato entre Ré e Lá alternado com o acorde de $7^{a}$ maior (subtónica), dividido em intervalos de $5^{\text {a }}$ pelas duas mãos (mão esquerda Dó - Sol e mão direita Mi - Si) na $1^{\underline{a}}$ e $3^{\underline{a}}$ secções. Na $2^{\underline{a}}$ secção é mantido um bordão executado pela mão esquerda do piano, também este constituído por duas $5^{\underline{a}} \mathrm{~s}$ sobrepostas, correspondente a acordes de $9^{\text {a }}$ numa alternância de I e IV graus, e posteriormente de IV e VII ( $2^{\circ}$ tempo de c. 45 a c. 53$)$. Esta harmonização pode ser interpretada no sentido de induzir auditivamente a gaita-de-foles, dado a ênfase conferido aos bordões com uma nota muito grave (duas $8^{\mathrm{a}} \mathrm{s}$ abaixo da melodia, como na gaita-de-foles), à função conferida ao VII grau de subtónica, assim como à predominância das $5^{\mathfrak{a}} \mathrm{s}$ na mão esquerda do piano, resultante da opção de posicionamento dos acordes, e que sublinha a linguagem modal. $\mathrm{O}$ pianista pode então atribuir um papel de relevo a esta passagem da mão esquerda do piano, também valorizada dentro da função rítmica sincopada e projetando bem a sonoridade destes sons graves, através da utilização do peso do braço.

Em Pírrico prevalecem as indicações de $f f$ e fff, acentuações, martelato, come campane, assim como dolce, $p$ e $p p$, que indica uma exploração dos extremos da sonoridade dos instrumentos. As sugestões de pedal no piano remetem também para a abertura das ressonâncias, como por exemplo entre os cc. 12 e 
15, em que este não é mudado. Cabe ao piano, no seu enquadramento com as cordas, uma função estruturante, vivenciada através das introduções da cada secção e da sua função rítmica, elemento determinador para a separação das três secções, através das já mencionadas células rítmicas caracterizantes, que deverão ser executadas com determinação. A indicação inicial de in modo popolare sugere a sua característica primordial e segundo Carrapatoso (2009, p. 7),

a energia rítmica é-lhe dada por um tempo vivo de giga e ainda pela alternância entre o 6/8 de base e o $3 / 4$ que emerge de uma forma enérgica, quase rude (no violoncelo no c. 13, por exemplo, ou no violino no c. 38). O efeito geral é martelatíssimo, como é pedido na partitura, e o piano sugere-nos um registo refulgente de bronze, como os sinos a rebate da minha aldeia.

Esta peça constrói-se performativamente numa aproximação imagética para com a canção Mirandum se fui à la guerra que the deu origem, consubstanciada na significação do seu título, uma vez que a dança pírrica tem uma origem guerreira. ${ }^{2}$ A função do piano divide-se entre o protagonismo, entre o acompanhamento e a gestão dos momentos de transição entre cada secção, à semelhança da peça anterior, mas dentro de uma caracterização sonora mais percussiva. Sobre a função do pianista na $1^{\underline{a}}$ e $3^{\underline{a}}$ secções, assim como nas transições, já foi mencionada a premência da manutenção inabalável do tempo e do sentido do ritmo de giga. A partir do lançamento da frase melódica que inicia a $2^{a}$ secção ( $2^{o}$ tempo do c. 29) a opção interpretativa foi fazer sobressair esta mesma, uma vez que é o piano que a contém. Como a mão esquerda mantém o referido ostinato, foi assim mantido um sentido de sustentação rítmica. A textura adensa-se na frase em que a mão direita do piano contém a melodia realizada a duas vozes à distância de intervalos de $3^{\text {a }}$, a partir do $2^{\alpha}$ tempo do c. 37, tendo sido tomada a opção de continuar a fazer sobressair a voz mais aguda, que detém a melodia. Quando a melodia é colocada uma $3^{\text {a }}$ acima à versão original ( $2^{\underline{o}}$ tempo do c. 45 a $2^{\underline{o}}$ tempo do c. 53) e passa a ser acompanhada por uma voz colocada à distância de uma $5^{\mathbf{a}}$ abaixo, outra configuração interpretativa foi pensada: uma vez que todas as vozes introduzidas no piano são executadas pelas cordas, e como a indicação na partitura menciona martelatissimo. O som pianístico foi direcionado para uma ideia de densidade textural, em que todas as vozes são encaradas como um corpo sonoro, deixando de existir uma voz evidenciada.

\footnotetext{
2 Pírrica - Dança guerreira, de origem dórica, que se praticava tanto em Atenas como em Esparta, e na qual os antigos gregos eram exercitados desde a infância, a fim de se prepa rarem para enfrentar os combates (Machado 1981, vol. IX, p.140).
} 


\subsection{Pícaro - Mira-me Miguel}

Pícaro, escrito no modo mixolídio, será iniciado por uma pequena introdução no piano e violoncelo a que se seguirão as referidas sucessões de refrão e quadra; estas sucessões delineiam uma divisão em cinco secções e terminam com uma Coda (c. 85). Carrapatoso (2009, p.8) preconiza que em Pícaro

a sonoridade é metálica. O ritmo ben'articolato ancora-se firmemente nos ostinati do piano que lhe dão um carácter de máquina locomotiva. Todos os instrumentos ululam num registo aqui irónico, ali pícaro, além virtuoso.

A estruturação original da cantilena, uma sequenciação de refrão e quadra, é mantida em Pícaro, sendo acrescentada uma pequena introdução e uma Coda, como se pode verificar na Figura no 3 .

\begin{tabular}{|c|c|c|c|c|}
\hline $\begin{array}{c}\text { 1a secção } \\
\text { (cc. } 1 \text { a 20) }\end{array}$ & $\begin{array}{l}\text { 2a secção } \\
\text { (cc. } 21 \text { a 36) }\end{array}$ & $\begin{array}{c}\text { 3a secção } \\
\text { (cc. } 37 \text { a 52) }\end{array}$ & $\begin{array}{c}\text { 4a secção } \\
\text { (cc. } 53 \text { a 68) }\end{array}$ & $\begin{array}{l}\text { 5a secção } \\
\text { (cc. } 69 \text { a 88) }\end{array}$ \\
\hline $\begin{array}{l}\text { introdução } \\
\text { pn + vlc } \\
\text { refrão } \\
\text { vl - melodia } \\
\text { vla - 2a voz } \\
\text { vlc -ostinato } \\
\text { pn - ostinato }\end{array}$ & refrão (=) & refrão (=) & refrão (=) & $\begin{array}{l}\text { refrão }(2 x) \\
\text { vl+vla+vcl-melodia } \\
\text { pn (=) }\end{array}$ \\
\hline $\begin{array}{l}\text { estrofe } \\
\text { vl - melodia } \\
\text { vla - 2a voz } \\
\text { vlc + pn - } \\
\text { ritmo / harmonia }\end{array}$ & $\begin{array}{l}\text { estrofe (=) } \\
\text { harmonização } \\
\text { diferente }\end{array}$ & $\begin{array}{l}\text { estrofe } \\
\text { vl + vla (=) } \\
\text { vlc + pn - } \\
\text { 5a } s+\text { acordes }\end{array}$ & $\begin{array}{l}\text { estrofe } \\
\text { lentiss, sub. } \\
\text { vla - melodia } \\
\text { pn + vlc + vl - } \\
\text { notas longas }\end{array}$ & $\begin{array}{l}\text { ornatos } \\
\text { vl } \\
\text { pn - ostinato }\end{array}$ \\
\hline $\begin{array}{l}\text { ornatos } \\
\mathbf{v l}+\mathbf{v l a}+\mathbf{v c l} \\
\text { pn - ostinato } \\
=\text { intr. }\end{array}$ & ornatos (=) & $(=)$ & $\begin{array}{l}\text { ornatos } \\
\text { tempo primo } \\
\mathbf{v l}+\mathbf{v l a} \\
\mathbf{v c l} \text { - nota longa } \\
\text { pn (=) }\end{array}$ & $\begin{array}{l}\text { coda } \\
\text { pn - citação }\end{array}$ \\
\hline
\end{tabular}

Figura 3: estruturação de Pícaro

A sucessão de blocos constituídos por um refrão e uma estrofe acontece quatro vezes, e é finalizada com uma dupla exposição do refrão a que se segue uma Coda, estruturando-se Pícaro em cinco secções. Na $4^{\underline{a}}$ secção a respetiva estrofe (c. 61) é apresentada num andamento mais lento, que logo é retomado quando reaparece o refrão (c. 69). O violino executa a melodia, a viola vai 
comentando através de diversas variações da melodia principal numa segunda voz, e o violoncelo tem um acompanhamento rítmico e harmónico, constituindo-se como um aliado do piano. A segunda voz da viola é sempre igual no refrão, mas variada em cada estrofe: na $1^{\underline{a}}$ (c. 12) realiza a melodia num registo mais grave uma $6^{\underline{a}}$, na $2^{\underline{a}}$ (c. 29) executa um pequeno arpejo, na $3^{\underline{a}}$ (c. 45) repete a $1^{\underline{a}}$, e na $4^{\underline{a}}$ protagoniza a melodia num andamento mais lento. Cada secção é finalizada com uma sucessão de células de características melismáticas nas cordas. A $4^{\underline{a}}$ secção, em que a viola canta o tema num andamento mais lento (cc. 60 a 64) e o violoncelo executa um pequeno solo (cc. 65 a 68), foi encarada em termos de interpretação como uma ponte para a célula melismática que antecede a última secção. Esta transição requer uma cooperação muito comunicada entre o violoncelista e o pianista, uma vez que a viola detém um momento solístico com alguma liberdade interpretativa. $\mathrm{O}$ violoncelo e o piano vão ser os elementos responsáveis pelo retomar do tempo rigoroso, sendo primordial a coordenação conjunta do c. 68. Neste c. 68 o violoncelo tem um accel. molto, e o piano articula conjuntamente a última nota da tercina do $2^{\underline{0}}$ tempo, catapultando a entrada no compasso seguinte, em conjunto com o violino e o violoncelo. Durante os ensaios ficou estipulado que o pianista seguiria o violoncelista, baseando-se numa atitude de escuta muito atenta.

O refrão irá sempre ser antecedido por uma sustentação de um bordão realizado na mão esquerda do piano e no violoncelo, na primeira vez articulado em conjunto, e nas seguintes articulado com um desfasamento de uma colcheia, com um pequeno ostinato no registo médio do piano. Este material composicional já foi apresentado na introdução e encontra-se sobreposto à célula melismática das cordas, criando assim dois blocos: um assinala a finalização da estrofe, e o outro a introdução do próximo refrão. Este bordão constitui-se num uníssono entre violoncelo e piano, onde a viola e o violoncelo respondem ao violino (c. 17, c. 30, c. 49, c. 69) com exceção da 5ª secção, em que o bordão do violoncelo passa para um Mi agudo (cc. 69 a 72). Na primeira articulação do referido bordão é afirmada a necessidade de solidariedade rítmica entre o violoncelista e o pianista, elemento que vai perdurar em momentos fundamentais no decorrer da peça. Neste caso concreto foi considerado que o pianista sinalizaria a entrada. Pianisticamente a opção residiu numa execução desta oitava inicial com as duas mãos, para que a projeção do som fosse eficaz dentro da dinâmica requerida, fff, e que a deslocação que se segue fosse realizada com segurança, para não comprometer a precisão rítmica do ostinato que se segue. $\mathrm{O}$ ostinato do piano requer muita precisão na sua execução, por um lado devido à exigência interpretativa que se revê num resultado rítmico de constante repetição mecânica sem valorização de nenhum dos sons, e por outro lado porque desta precisão depende todo o grupo. Os outros instrumentistas dependem absolutamente do pianista para que a contagem até ao compasso 5 seja bem-sucedida, momento em que entram 
em simultâneo; a partir daí a precisão do pianista garante a coesão da junção instrumental. A resolução pianística residiu na opção de alternar a mão direita com a mão esquerda, colocando a mão esquerda por cima da mão direita e utilizando a dedilhação mais natural para as mãos nesta posição: o $2^{\underline{o}}$ e o $4^{\underline{0}}$ dedos. A imagem descrita anteriormente nas notas de programa de Carrapatoso é um elemento fundamental para a construção da imagética do pianista, tornando-se um elemento facilitador da execução pretendida: o movimento da locomotiva.

Quanto às sucessões melismáticas apresentadas ao longo de Pícaro, a última vez na $5^{\underline{a}}$ secção será uma exceção (c. 82). Nessa $5^{\underline{a}}$ secção o violino relembra estes melismas, e o violoncelo e a viola retomam uma sequência de pequenos arpejos presente na $1^{\underline{a}}$ e $2^{\underline{a}}$ estrofes na parte do violoncelo (cc. 15 a 16 e cc. 31 a 32). Interpretativamente estas duas ocasiões foram pensadas como uma transição e no final da peça como um stretto, uma vez que se encontram sobrepostos a uma proposta melódica pertencente a outro contexto estrutural da peça, reforçados pelo crescendo muito intenso. As referidas células melismáticas têm uma correspondência no texto poético à interjeição $A h$ ! $A h$ ! $A h$ !, expressão interligada como o sofrimento expresso neste mesmo. $\mathrm{O}$ jogo de sobreposição da finalização e início de cada secção foi pensado performativamente como uma exponenciação do caráter irónico de Pícaro, devendo por consequência ser muito enfatizado em termos de sonoridade através da exploração dos contrastes expressos na dinâmica. Tendo em vista a segurança do grupo na entrada de cada nova secção, o pianista deve ter bastante presente qual o instrumento que articula o último melisma, de forma a entrar seguramente no próximo ostinato, sem qualquer hesitação.

Como já foi mencionado, o piano assegura o carácter rítmico de Pícaro através do ostinato de semicolcheias sempre presente nos refrões, e também dos ritmos curtos e pontuados da $1^{\underline{a}}$ e $2^{\underline{a}}$ estrofes. Na $3^{\underline{a}}$ estrofe o piano junta-se às semicolcheias do violoncelo, e na $4^{\underline{a}}$ estrofe o ritmo expressa-se por valores longos, em paralelo com a característica lírica da melodia já exposta anteriormente. Ainda no refrão, na parte do violoncelo existe um ostinato que determina um desfasamento da acentuação rítmica em relação à melodia e ao compasso estipulado, e que se constitui interpretativamente numa visão de um apontamento irónico, uma vez que estabelece uma relação com os outros instrumentos de desequilíbrio perante a estabilidade gerada nos outros ostinatos existentes. Como se pode verificar no Exemplo 3, este ritmo é gerador de uma sensação de instabilidade patente na articulação repetitiva de uma célula, que devido à intermediação de uma pausa de semicolcheia se vai articular umas vezes na parte forte do tempo e outras na parte fraca do tempo, como no caso da $2^{\underline{a}}$ articulação: 


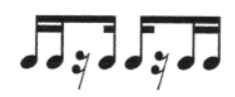

Exemplo 3: células rítmicas do violoncelo

Quando a organização da escrita rítmica não coincide com a métrica proposta, a concretização interpretativa desse momento deve ser refletida. A coesão sonora do grupo pode ser afetada uma vez que é expressa no violoncelo uma sobreposição de ideias com uma cinética não convergente com o compasso estabelecido, enquanto os outros intervenientes seguem a acentuação inerente a um compasso de 2/4. Segundo Lopes (2003, p. 150),

No processo de estabelecer uma determinada sequência rítmica, o nosso sistema cognitivo procura e prefere a organização mais estável. Isto basicamente significa uma sincronização entre as pulsações rítmicas e uma determinada métrica, de modo a que as pulsações acentuadas são perceptualmente colocadas em pontos métricos fortes. Se após a inferência de uma determinada sequência rítmica, pulsações salientes são atribuídas a pontos métricos fracos, o efeito será de instabilidade e gerando sensação de cinética ${ }^{3}$.

Este desfasamento das células rítmicas entra em confluência com a resolução interpretativa já proposta atrás, o que exige do pianista uma atitude de condução rítmica inabalável, para que a continuidade da frase não seja posta em causa devido à sensação de instabilidade que pode surgir entre os elementos do quarteto.

Pícaro é uma peça muito ritmada e articulada, onde predominam os staccatos e acentuações, cujo carácter repetitivo é desde o início assinalado pelo compositor, sob a indicação meccanico ed ostinato. No momento da sua execução é necessário ter em conta o trabalho de cariz estrutural para o grupo, delineado numa parceria entre o violoncelo e o piano, e de que serve de exemplo a já mencionada articulação inicial da nota grave a anunciar o início de cada secção, assim como algumas simultaneidades rítmicas. São aqui explorados os extremos da dinâmica das possibilidades sonoras dos instrumentos: a ressonância provocada pelo dó grave usado como bordão, com indicação dinâmica de fff como pano de fundo das $3^{\underline{a}}$ s alternadas do piano (cc. 1 a 4 ), é de imediato contrastada com as mesmas $3^{\underline{a}}$ s alternadas com a indicação de secco e staccato (cc. 5 a 12), cuja dinâmica será $p$. O refrão contém indicações de alternância súbita entre $m f-p p, f-p, p p-p p p$, assim como, na referida célula melismática, sucedem-se $f$-ff-fff.

\footnotetext{
${ }^{3}$ In the process of establishing a rhythmic construct, the cognitive system will strive for the most stable organisation; this basically means a tuning-in between the rhythm stratum and metre stratum, such that accentuated pulses are placed at strong metrical points. If, after the inference of a particular rhythmic construct, salient pulses are assigned to w eak metrical points, the effect will be instability and hence the release of kinesis.
} 
Carrapatoso (2009, p. 8) afirma que

a citação de Mozart no fim da peça, num registo agudo de caixinha de música, tem um sentido mahleriano de visão irónica e anti-picarda da vida que a própria canção narra: pobreza, abandono, vidas duras e ásperas, que, empedernidas, espargem vinagre e transpiram humor negro.

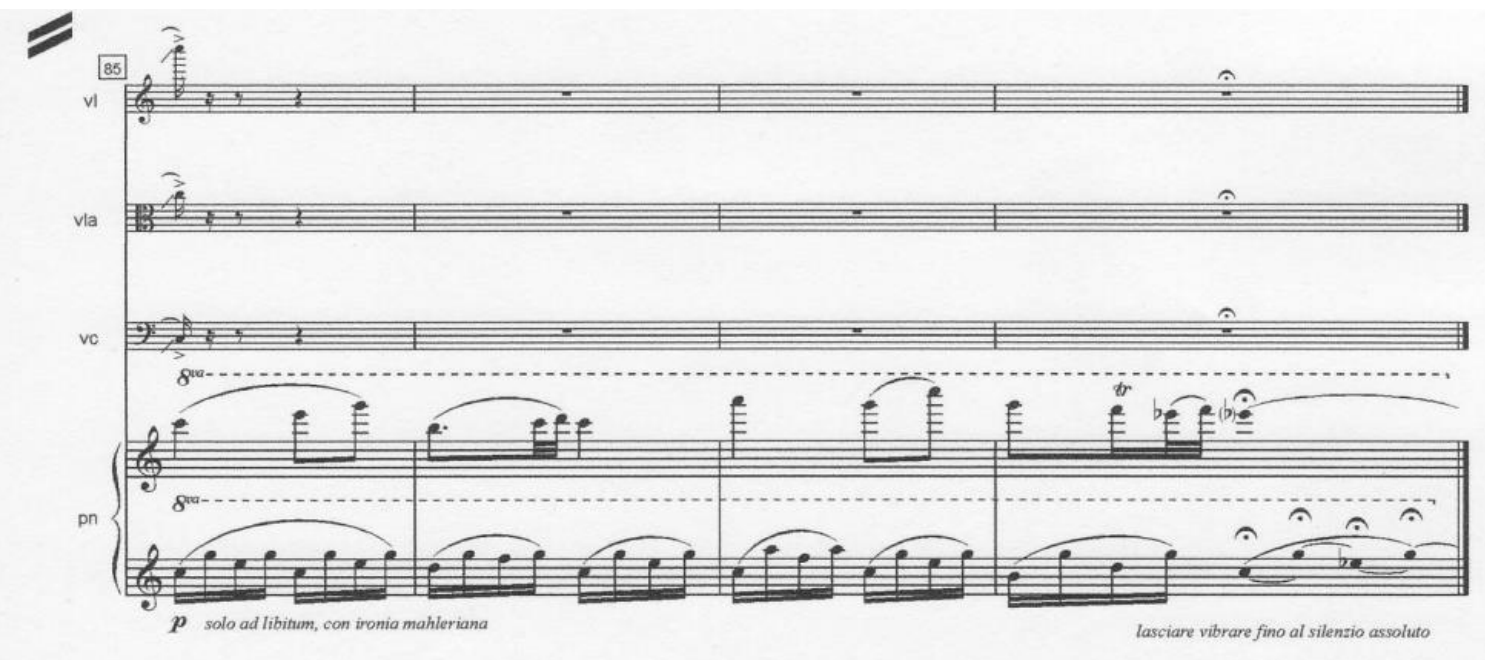

Exemplo 4: citação

A citação do tema do $1^{\circ}$ andamento da Sonata para piano KV 545 de W. A. Mozart, mostrada no Exemplo 4, constitui a Coda desta peça. Como se observa ali, o tema encontra-se no extremo agudo do piano e contém as seguintes instruções: solo ad libitum, con ironia mahleriana (c. 85) e lasciare vibrare fino al silenzio absoluto. A solução interpretativa foi pensada dentro de uma execução da melodia imbuída de simplicidade, levando a que o recurso irónico sobressaia devido ao registo muito agudo da frase, assim como na resolução picarda patente no acorde final e no trilo. Foi estipulado pelo quarteto que os compassos anteriores deveriam ser executados num crescendo muito intenso, levado ao limite da sonoridade, assinalando assim o contraste com a frase final, executada num registo de ingenuidade ambivalente, dentro de uma sonoridade e expressividades contidas. A ironia patente nesta citação pode ser encarada pelo pianista como uma ligação ao texto da canção, semanticamente oposto ao aparente ambiente festivo e de paródia, e que menciona a fome (Tengo três meninos, não tengo que lhe dar, pongo me'a cantar e'a ensiná-los a bailar), a solidão (quero-me casar e nom acho quem me queira! Vi venir la gaita, lo gaiteiro não! Ó que pena tengo no meu coração!) e a crua realidade de que a vida prossegue apesar de todas as dificuldades (Baila Pedro, baila! - "Senhora quero pão!!! Baila mais um pouco que $\log o$ to darão!). A palavra pícaro ${ }^{4}$ liga-se semanticamente a um elemento de sátira patente em todos os sinais humorísticos já mencionados: os

4 Pícaro - Ardiloso, astuto, que é patife. // Ridículo. (...) // Homem ardiloso. (Machado 1981, vol. IX, p. 60). 
extremos da dinâmica a serem mudados bruscamente, o final da citação contida no modo menor, assim como o conteúdo temático detentor da ironia expressa no poema que gerou a sua canção original. Tratando-se, pois, de uma peça aparentemente muito alegre, considera-se que emana uma mensagem de amargura patente em todos estes recursos. Esta ambivalência de mensagens deve reportar-se nos recursos interpretativos através da exploração máxima dos elementos contrastantes já descritos nesta análise; de reter que mesmo nos momentos que aparentemente são mais suaves em termos de intensidade sonora, existe sempre uma mensagem de amargura que se deverá repercutir na atitude interpretativa. Por exemplo, no c. 73, na indicação de $p$ para as cordas, existe um apontamento de quasi grotesco. Conclui-se assim que o ambiente sonoro de todo o grupo deve manter um caráter vigoroso e afirmativo dentro de uma articulação muito ritmada e procurar um registo sonoro que se coadune com a imagem desta peça.

\section{A Relação Metafórica nas Obras Analisadas}

O aprofundamento do conhecimento analítico das duas peças numa perspetiva pianística e de interseção com o grupo permitiu o conhecimento das figuras metafóricas induzidas pelo compositor através da partitura e das notas de programa e o desenvolvimento imagético do intérprete, através da criação do seu guião interpretativo consubstanciado no pensamento metafórico. Estabelecendo pontes semânticas entre as duas peças desenvolve-se um pensamento metafórico com uma base mais abrangente e que exponencia a maturação interpretativa. Considera-se construtivo refletir sobre possíveis intertextualidades da já enunciada construção em espelho, questionando-se quais as linhas condutoras identificáveis entre as duas peças. A similitude fonológica entre Pírrico e Pícaro, devem ser alvo de reflexão. Esta similitude confirma-se tematicamente e no tratamento rítmico.

Pianisticamente a ideia interpretativa foi constituída através da ideia metafórica da construção em espelho, o que se traduz numa procura de continuidades e descontinuidades entre as peças que se correspondem. Pírrico e Pícaro convergem em alguns parâmetros rítmicos, assegurados pelo piano: Pírrico inicia-se com um ostinato de semínima colcheia, ritmo que será executado por vezes com as duas mãos em simultâneo e por vezes apenas com a mão esquerda; Pícaro contém, em secções alternadas, o ostinato de semicolcheias, tendo assim estes ritmos funções idiossincráticas Lopes (2006). Ambas as peças são dotadas de uma exuberância afirmada pelo pianista logo no início e explicitada nos extremos da dinâmica: Pírrico contém um crescendo no piano nos três primeiros compassos entre $f$ e $f f f$, e Pícaro afirma-se com uma 
primeira nota entregue ao piano e violoncelo, num registo grave muito audível, com a indicação de fff.

Tematicamente, Pírrico e Pícaro sobressaem nalguns aspetos que geram pensamentos contraditórios no âmbito da obtenção de uma ideia performativa sustentada por fios condutores consonantes. Existem algumas ambivalências linguísticas que vão estabelecer um paralelo entre as duas peças. Ambas as canções populares são detentoras de um carácter extrovertido, enérgico e aparentemente muito alegre. Os poemas que as sustentam suportam, no entanto, mensagens de dor. Numa perspetiva interpretativa, Pírrico e Pícaro têm em comum a exposição irónica de dores muito profundas, patentes nos poemas de origem (Pírrico na sua origem descreve a morte de um guerreiro e Pícaro descreve o drama da pobreza) e destiladas nas melodias ritmadas e alegres; nestas obras essa ambivalência é extremada com mestria: Mirandum se fui a la guerra (Pírrico) descreve a história de alguém que espera pela volta de um soldado que partiu para a guerra e que acaba por receber a notícia da sua morte; por outro lado Mira-me Miguel (Pícaro) expõe a tristeza da fome e da solidão de uma mãe solteira com três filhos. Ambas as peças exigem aos intérpretes um inabalável estado enérgico, principalmente ao pianista que detém sempre o suporte rítmico, através dos ostinatos já mencionados. Porém, enquanto Pírrico nunca abandona o seu lado extrovertido, Pícaro tem dois momentos de rutura com este estado enérgico. Pícaro traz ao pianista o desafio de reflexão sobre o papel da citação nele contida e da respetiva indicação interpretativa. Pode-se inferir, numa perspetiva da construção de uma narrativa interpretativa uma intertextualidade mais aprofundada ligada aos dois compositores citados sob a égide de estratégias diferentes: por um lado Mozart, uma figura ligada à sua capacidade humorística contraposta com um trajeto de vida trágico, e por outro Gustav Mahler, que tinha por hábito recorrer à citação, quer dele próprio quer de outros compositores. Agawu refere (1996, p. 226): "Gestos de negação - chegamos a essa conclusão - são ocasiões mais ricas para a construção de significados do que gestos de declaração normativa" ${ }^{5}$.

Esta citação foi inferida pelo intérprete como um gesto metafórico de contradição e de rutura com a escrita de toda a peça, acontecendo o mesmo com o excerto temático entre os cc. 61 e 67; este excerto, muito mais lento, contém um esmorecimento implícito. Interpretativamente foi encarado como uma quase desistência da capacidade de sempre transportar as dores latentes de alguém sofredor, estado anímico muito evidenciado na tradição popular portuguesa. Este procedimento foi assumido como um procedimento irónico, confirmado posteriormente quando o estribilho da canção é retomado (c. 73): Carrapatoso sugere às cordas quasi grotesco, numa localização melódica que

${ }^{5}$ Gestures of denial, we have come to believe, are richer sites for the construction of meaning than gestures of normative enactment. 
corresponde linguisticamente à frase supostamente feminina e charmosa Mirame Miguel, que assim estou de bonitinha.

Estas relações de intertextualidade expostas até agora constituem relações metafóricas passíveis de criar uma congregação interpretativa e um guião para o quarteto, proporcionando a perceção e construção de uma contextualização convergente. Assumindo que a atividade performativa em grupo deve pressupor a veiculação de um discurso assente em pontos comuns a decidir pelos intérpretes constituintes deste mesmo grupo, infere-se que existem alguns pontos paralelos com a linguagem propriamente dita. Num estudo realizado sobre a constituição semântica da metáfora na linguagem, Stern (2010, p. 274) afirma que

O papel do significado metafórico, analisado como personagem, é especificar como a interpretação de uma metáfora - seu conteúdo, ou seja, o conjunto de características que pertencem às suas condições de verdade - depende e varia com um parâmetro específico do seu contexto, nomeadamente, um conjunto particular de pressupostos associados no contexto com o seu veículo literal. A competência semântica do palestrante sobre metáfora, como a competência semântica que subjaz a sua capacidade de usar demonstrativos, consiste no conhecimento desse significado, ou personagem, ou seja, uma função das propriedades associadas metaforicamente relevantes ao conjunto de contextos de pressuposições para o subconjunto particular de propriedades que constituem o conteúdo da metáfora nesse contexto. ${ }^{6}$

Assim sendo, esta análise estabelece uma ponte com uma ideia interpretativa da constituição de um mapa de imagens provenientes de diversos contextos entrecruzados: o imaginário coletivo nacional consubstanciado na tradição popular e no passado histórico, o ideário cultural ocidental e a ligação ao passado da música erudita ocidental.

Cook (1992, p. 362-363) alerta para a primazia da mensagem retida pelo intérprete e da imagem construída a partir da leitura e contextualização da obra para a abordagem interpretativa; a decifração do código propriamente dito é, por conseguinte, pouco determinante para a construção da interpretação. A abordagem analítica por parte do intérprete requer o estabelecimento das linhas condutoras da sua atitude, tal como é demonstrado por Rothstein (2005, p. 237).

\footnotetext{
${ }^{6}$ The role of metaphorical meaning, analyzed as character, is to specify how the interpretation of a metaphor - its content, namely, the set of features that belong to its truth-conditions depends on and varies with a specific parameter of its context, namely, a particular set of presuppositions associated in the context with its literal vehicle. The speaker's semantic competence in metaphor, like the semantic competence that underlies her ability to use demonstratives, consists in knowledge of that meaning, or character, namely, a function from the metaphorically relevant associated properties in the context set of presuppositions to the particular subset of properties that constitute the content of the metaphor in that context.
} 
O autor recorre a uma metáfora, estabelecendo uma associação ao trabalho realizado na montagem de uma peça teatral:

\begin{abstract}
Interpretar uma peça não é o mesmo que diagramar o seu enredo ou analisar as suas personagens como numa palestra; os atores que interpretam a peça necessitam de entender tanto o enredo quanto o personagem, se quiserem fazer justiça à obra. Da mesma forma, executar uma obra musical e analisá-la são atividades de diferentes tipos, mas o músico precisa entender não só os "personagens" da obra como também o seu "enredo" se o desempenho for atraente. O objetivo do músico ao efetuar uma análise não é apenas entender o trabalho por si só - pois a performance não é uma atividade tão despegada -, mas sim descobrir ou criar uma narrativa musical 7 .
\end{abstract}

\title{
5. Considerações Finais
}

Conclui-se então que a análise contribui para a criação da ideia interpretativa através da construção metafórica, afirmando-se como elemento valorizador da abordagem instrumental, do conhecimento e do estudo da obra. $\mathrm{O}$ intérprete necessita de consciencializar o pressuposto do enquadramento do pensamento metafórico implícito também à génese da obra.

A atitude analítica do intérprete englobou a integração das várias contextualizações da obra, desde a questão cultural até ao texto literário que as sustentou criativamente e que se interliga com os processos metafóricos. Estes processos metafóricos provenientes da linguagem literária desenvolvem a convergência do pensamento metafórico gerador e do pensamento metafórico performativo. A análise para a interpretação foi encarada como um processo aberto e passível de várias objetivações, uma vez que depende da perspetiva do intérprete, constituindo-se esta análise como uma reflexão e uma construção de um guião pessoal. Os pressupostos composicionais foram encarados como integrantes da imagem criativa do intérprete, assim como o ponto de construção das obras baseado nas assunções estilísticas e na imagem metafórica foram elementos de interação e geradores da criação da própria metáfora interpretativa. Desde modo poderá assim assumir-se que uma análise e interpretação que considere a metáfora não só se aproxima do pensamento

\footnotetext{
${ }^{7}$ Enacting a play is not the same thing as diagramming its plot or analyzing its characters in lecture, but the actors who are to perform the play need to understand both plot and character if they are to do the play justice. In the same way, performing a musical work and analyzing it are activities of very different kinds, but the performer needs to understand both the work's 'characters' and its 'plot' if the performance to be a compelling one. The performer's aim in undertaking an analysis is not only to understand the work for its own sake-performance is not so disinterested an activity as that - but to discover, or create a musical narrative.
} 
criativo da composição como também é um veículo privilegiado para a aproximação ao ouvinte - ontologicamente uma postura fulcral para a arte dos dias de hoje.

\section{Referências}

1. Agawu, Kofi. 1996. The Narrative Impulse in the Second Nachtmusik from Mahler's Seventh Symphony. In: C. Ayrey \& M. Everist (Ed.), Analytical Strategies and Musical Interpretation, p. 226- 241. UK: Cambridge University Press.

2. Bernardo, Ana Cristina. 2014. A Música de Câmara com Piano Produzida em Portugal: a diversidade de influências na geração nascida entre 1960/1970 e o seu reflexo na interpretação. Tese de Doutoramento em Música e Musicologia. Évora: Departamento de Música, Universidade de Évora.

3. Branco, João de Freitas. 2010. Giacometti, Michel Marie. In: Castelo-Branco, Salwa (Ed.), Enciclopédia da Música em Portugal no Século XX, p. 564-566. Porto: Círculo de Leitores, Temas e Debates.

4. Carrapatoso, Eurico. 2009. Pequena Reflexão de Eurico Carrapatoso a Propósito de sua Obra "O Espelho da Alma" [subsídios para o estudo de uma orografia musical portuguesa]. Lisboa: notas manuscritas do autor.

5. Cook, Nicholas. 1992. A Guide to Musical Analysis. UK: W. W. Norton \& Company.

6. Dortier, Jean-François. 2006. Dicionário das Ciências Humanas. Lisboa: Climepsi Editores.

7. Gloag, Kenneth. 2012. Postmodernism in Music. UK: Cambridge University Press.

8. Korsin, Kevin. 2010. Beyond Privileged Contexts: Intertextuality, Influence and Dialogue. In: Cook, N. \& Everist, M. (Eds.), Rethinking music. (3 ${ }^{\text {rd }}$ ed.), p. 5572. New York: Oxford University Press.

9. Lakoff, George \& Johnson, Mark. 2003. Metaphors we Live by. Chicago: The University of Chicago Press. 
10. Lopes, Eduardo. 2003. Just in Time: towards a Theory of Rhythm and Metre. Doctor of Philosophy Thesis. Southampton: Department of Music, University of Southampton.

11. Lopes, Eduardo. 2008. Rhythm and Meter Compositional Tools in a Chopin's Waltz. Ad Parnassum Journal, vol. 6, issue 11, p. 64-84.

12. Lopes, Eduardo. 2006. A Métrica Musical na Perceção do Movimento: o conceito gravitacional. VIS - Revista do Programa de Pós-Graduação em Arte da Universidade de Brasília, vol. 5, n² 2, p. 32-41.

13. Machado, José Pedro. 1981. Grande Dicionário da Lingua Portuguesa - Sociedade de Língua Portuguesa. Ponta Delgada: Amigos do Livro Editores.

14. Pinho Vargas, António. 2008. Cinco Conferências: especulações críticas sobre a história da música do século XX. Lisboa: Edição Culturgest.

15. Rosen, Charles. 2002. Piano Notes: the hidden world of the pianist. USA: Penguin Books.

16. Rothstein, William. 2005. Analysis and the Act of Performance. In: John Rink (Ed.), The Practice of Performance: Studies in musical interpretation, p. 217-240. UK: Cambridge University Press.

17. Samson, Jim. 2010. Analysis in Context. In: Cook, Nicholas \& Everist, Mark (Eds.), Rethinking Music ( $3^{\text {rd }}$ ed.), p. 35-54. New York: Oxford University Press.

18. Stern, Josef. 2010. Metaphor, Semantics and Context. In: Gibbs Jr., Raymond W. (Ed.). The Cambridge Handbook of Metaphor and Thought. (2 ${ }^{\text {nd }}$ ed.), p. 262-279. New York: Cambridge University Press.

19. Toop, Richard. 2004. Expanding Horizons: the International Avant-garde, 1962-75. In: Cook, Nicholas \& Pople, Anthony (Ed.). The Cambridge History of Twentieth-Century Music, p. 453-476. UK: Cambridge University Press.

20. Zbikowski, Lawrence. M. 2009. Music, language and multimodal metaphor. In: Forceville, Charles J. \& Urius-Aparisi, Eduardo. (Eds.), Multimodal metaphor, p. 359-381. Berlim: Mouton De Gruyter.

\section{Anexos}

p. 23 a 26 - Pírrico de Eurico Carrapatoso

p. 27 a 32 - Pícaro de Eurico Carrapatoso 
Pírrico

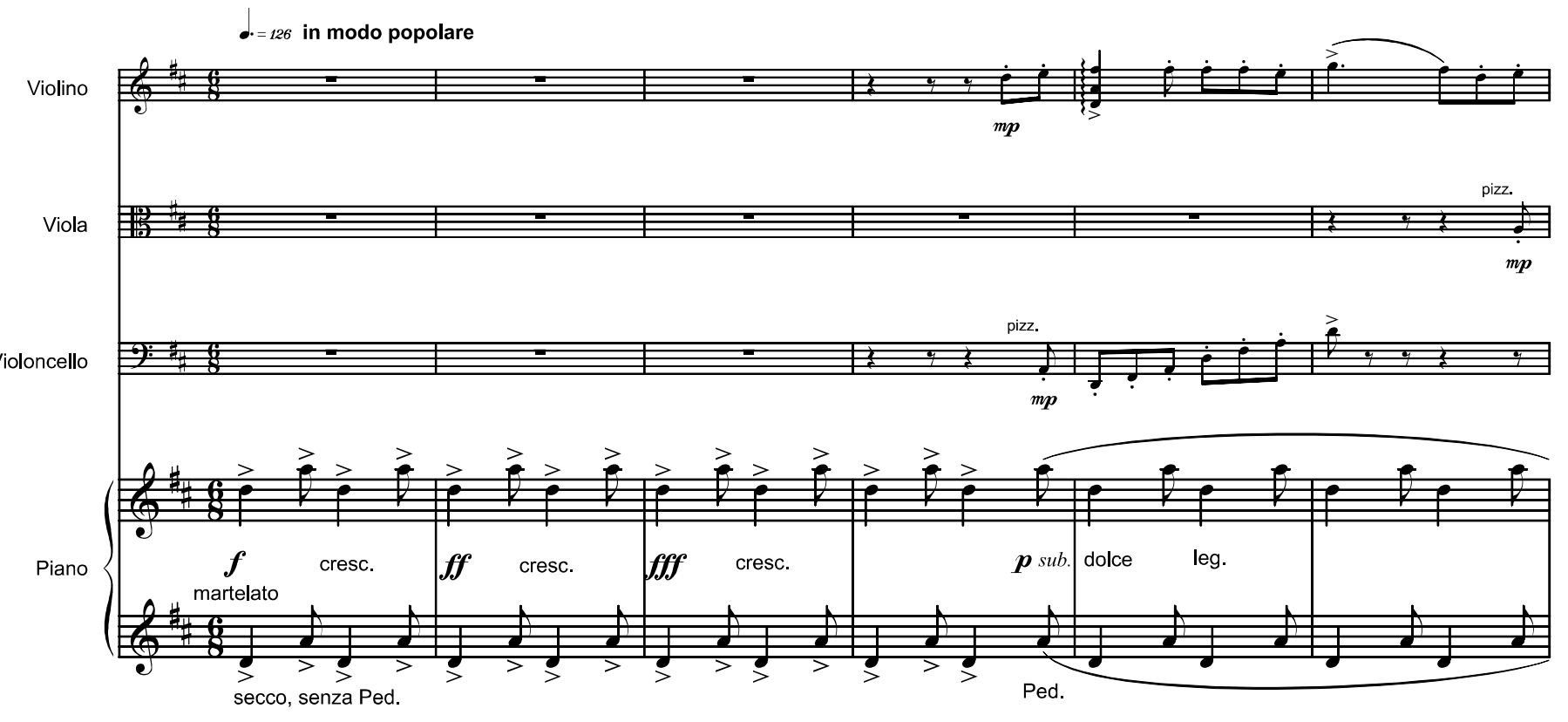

${ }^{7}{ }_{3}$

vla
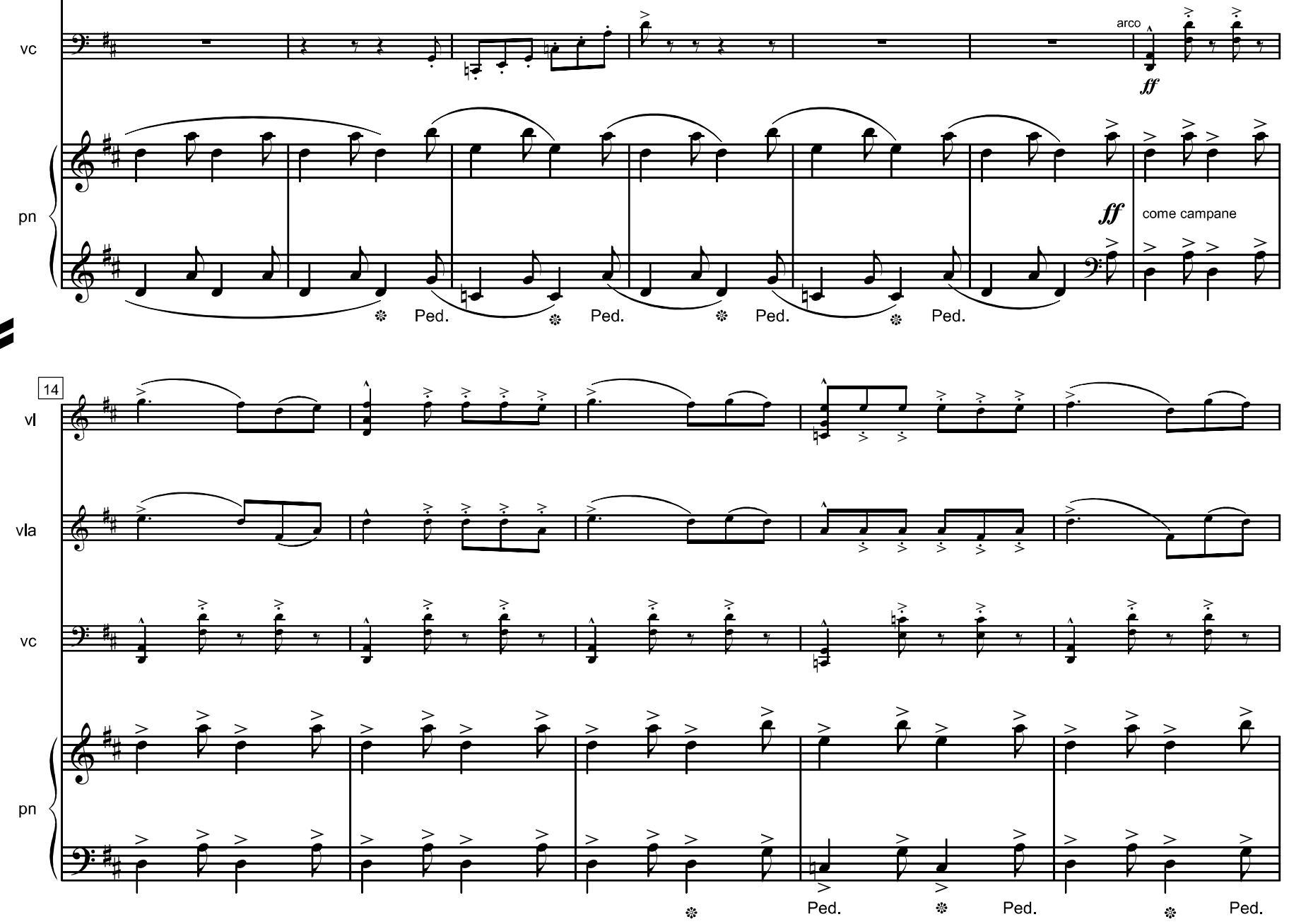
$\mathrm{VI}$ (leg.

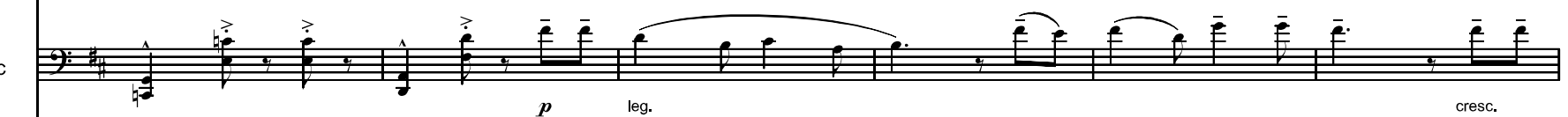

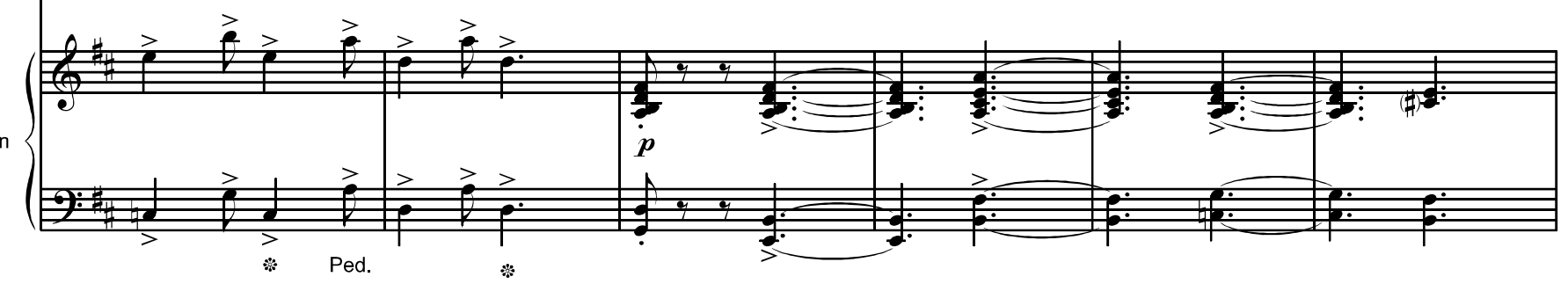
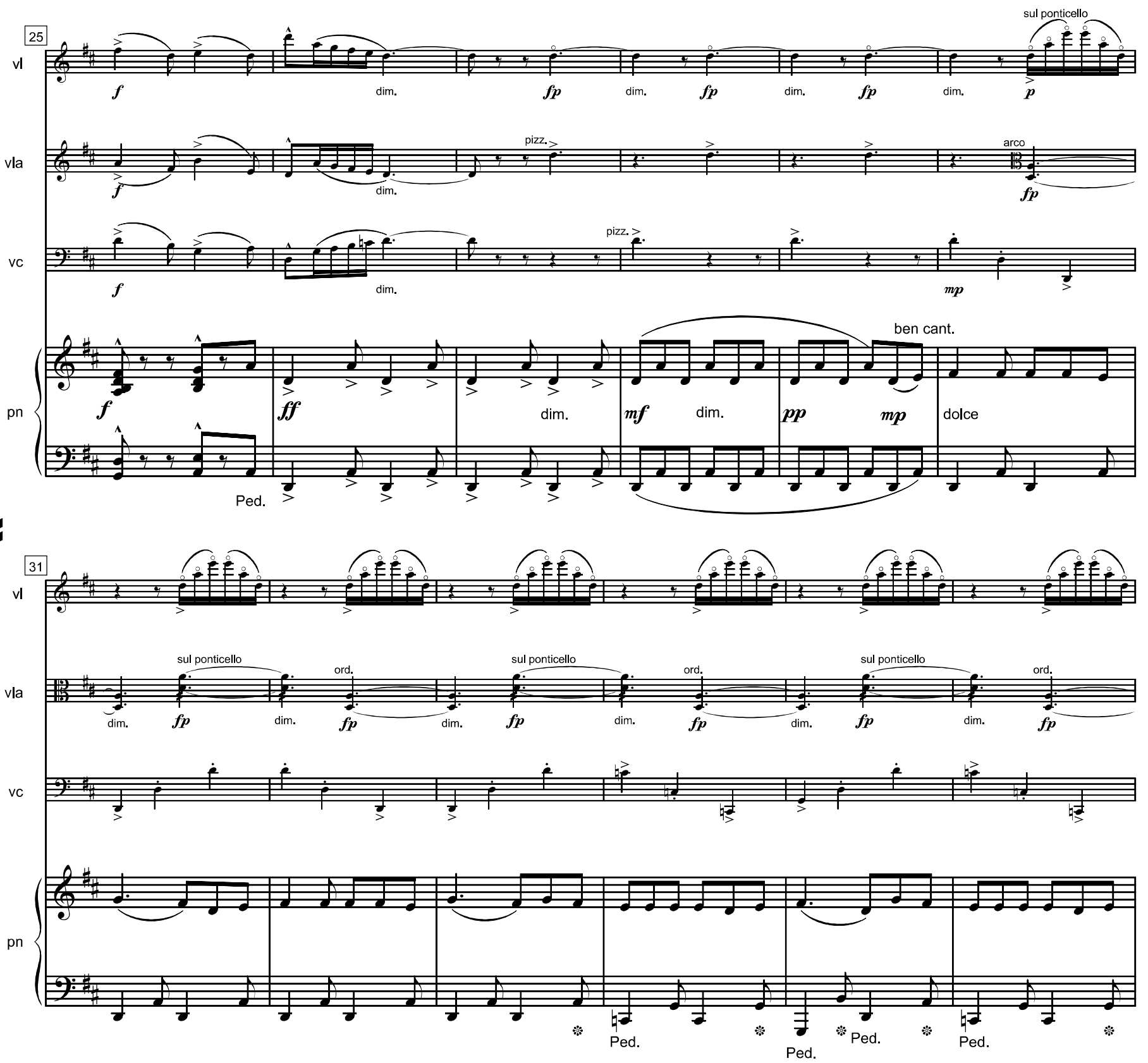
(1) Vla P:

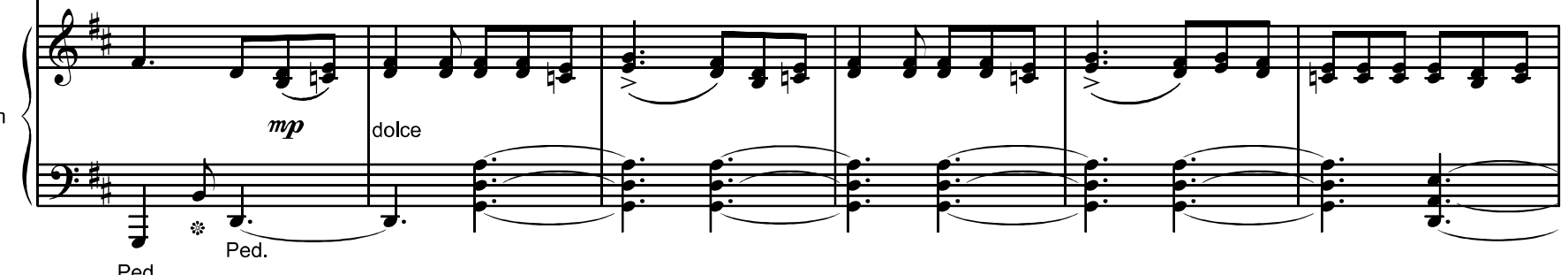
(3) vla

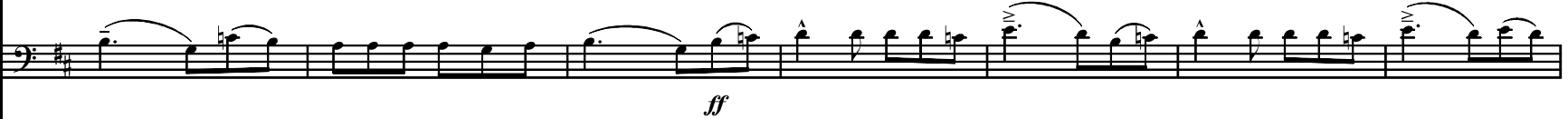

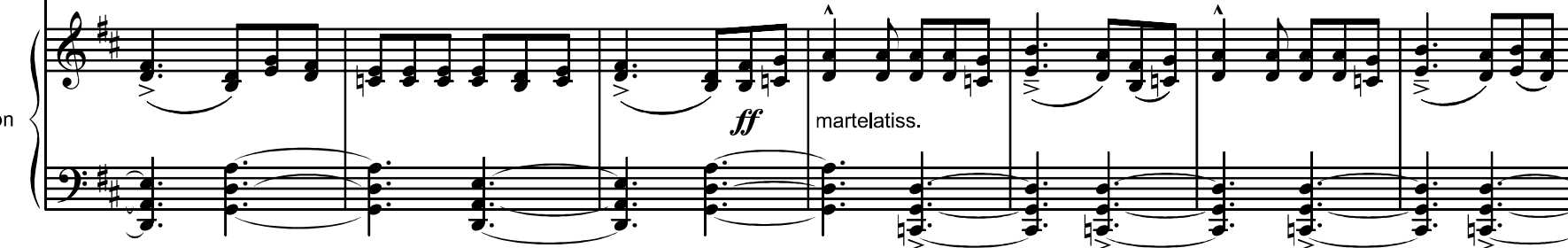

VI (1)

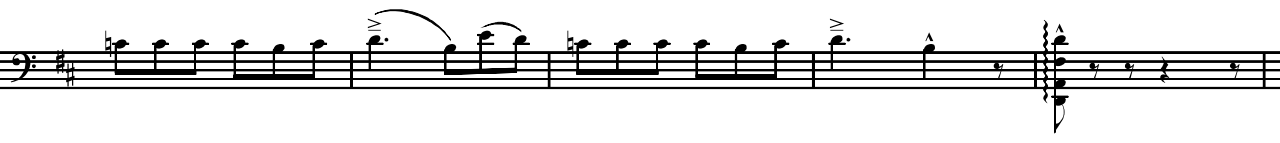

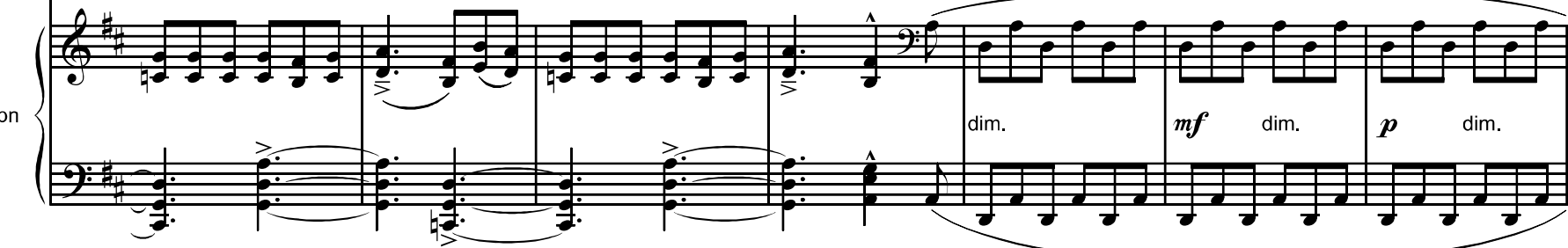




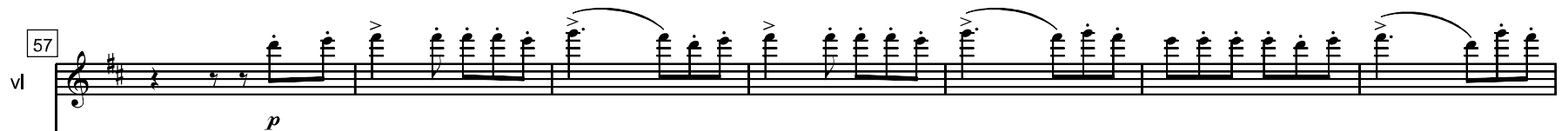
vla $v($ pizz.

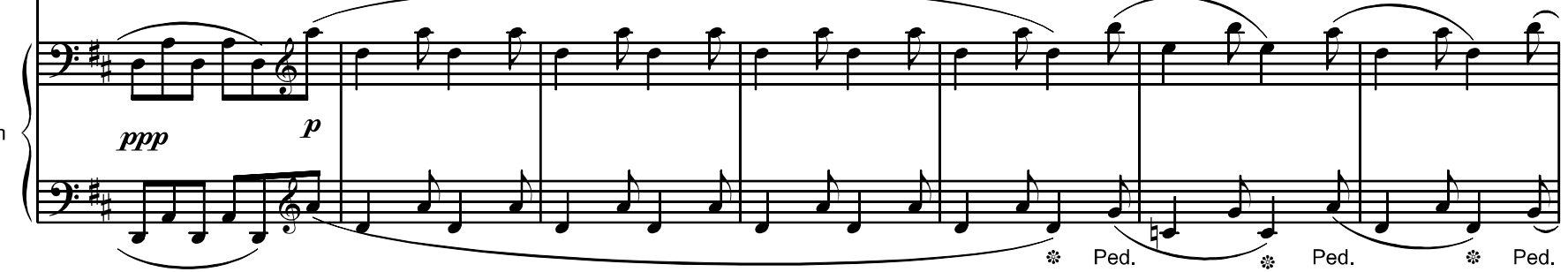

(1)

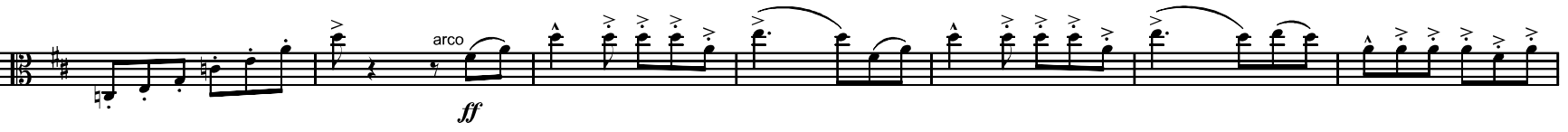
vc

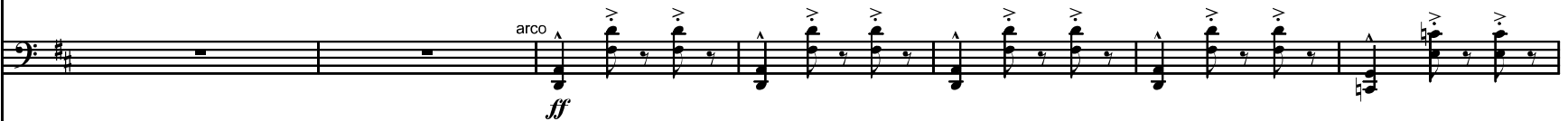

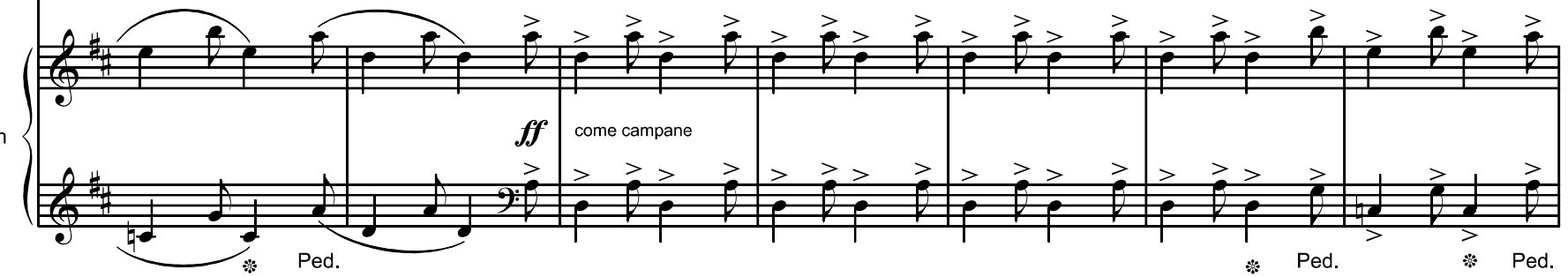

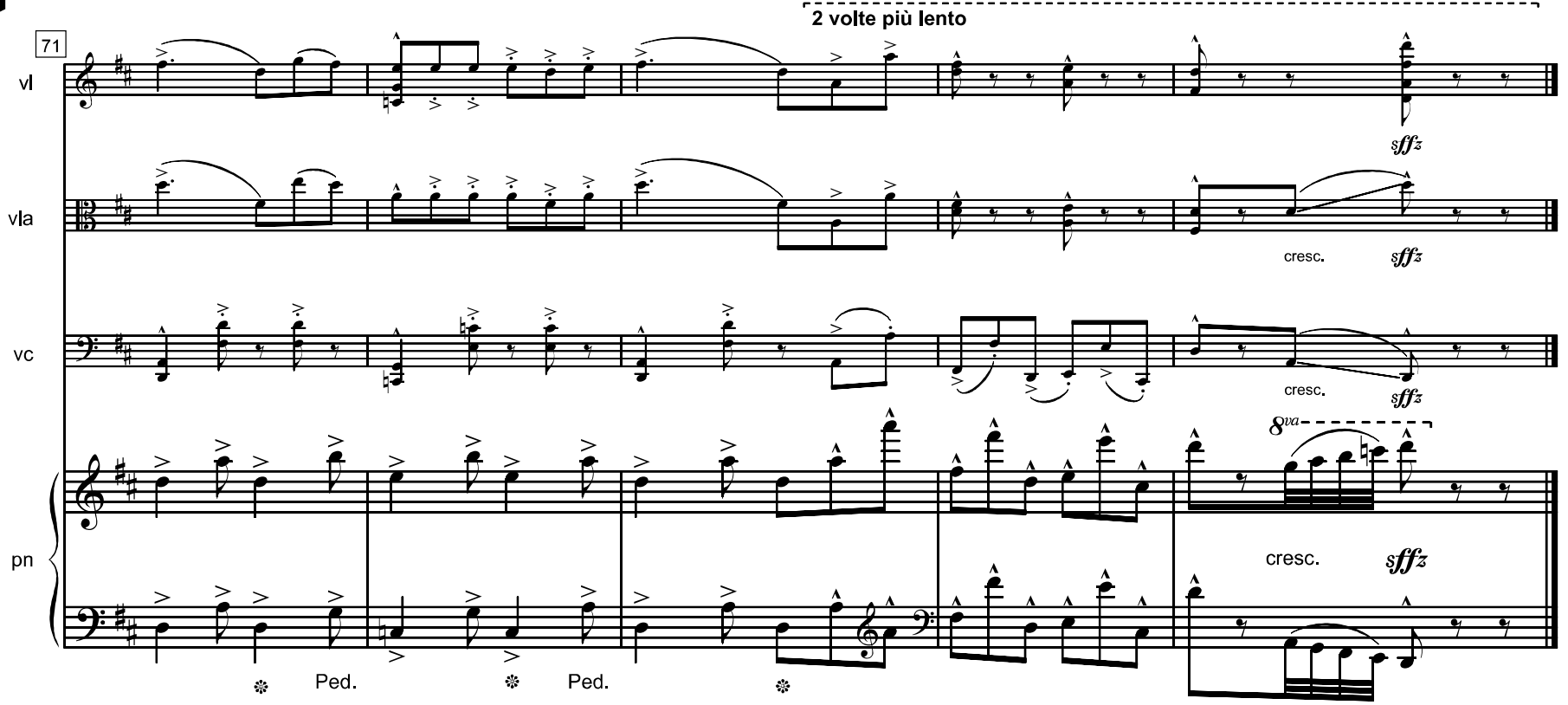


Pícaro

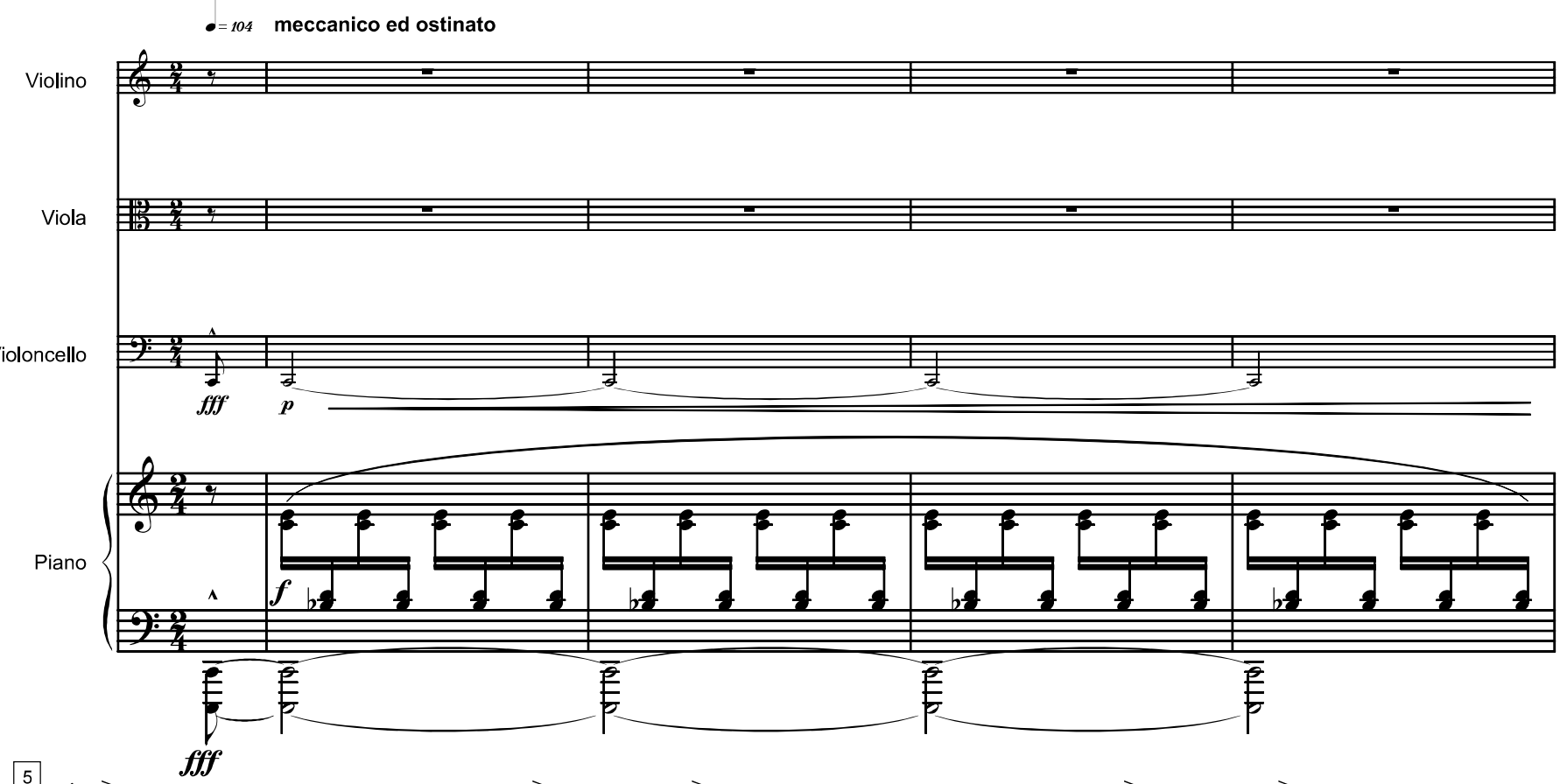

5

${ }_{f}$

vla

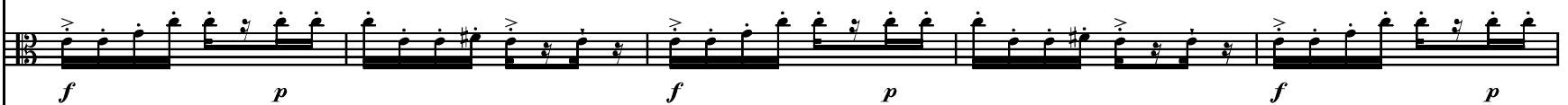

${ }_{m f}$

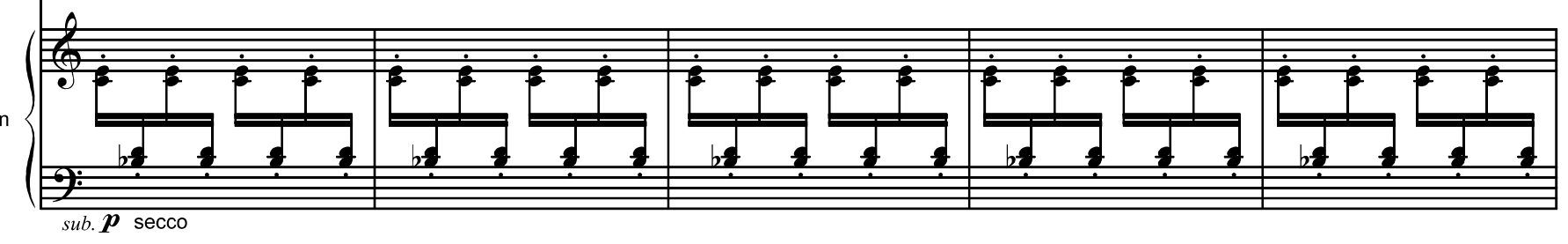

v10

vla

(l)

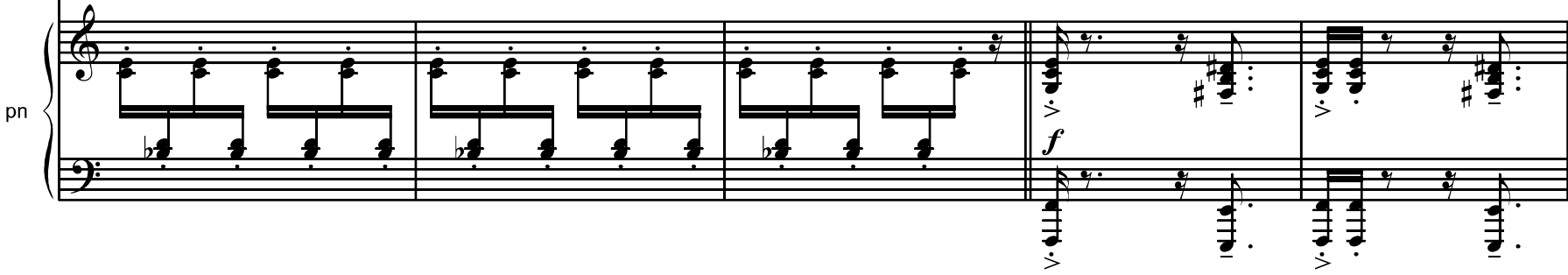


11

vla

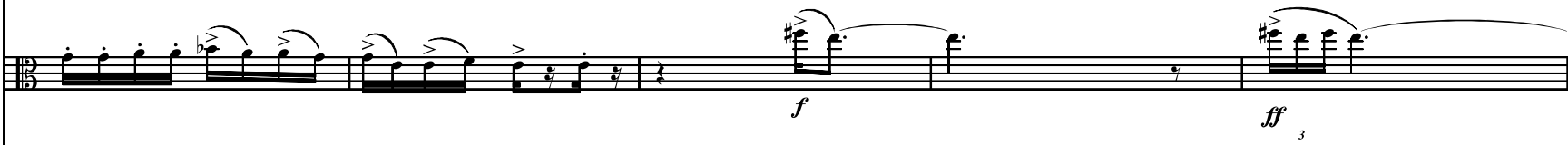

vc

${ }_{1}$

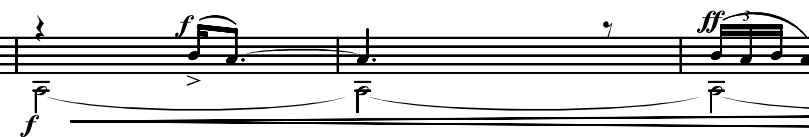

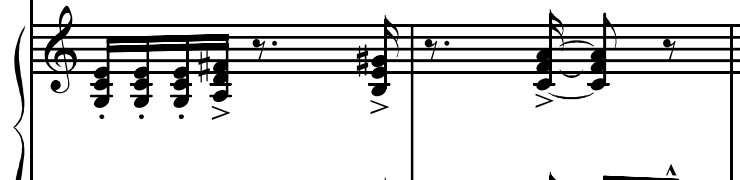

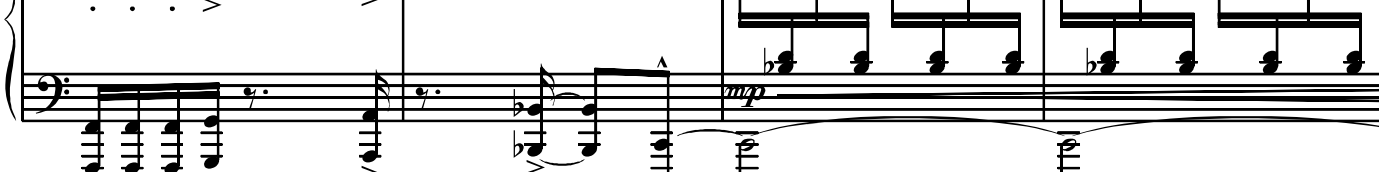

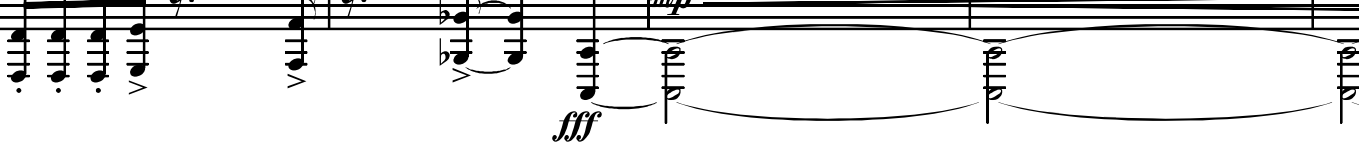

${ }_{f f f}$

vla

$\mathrm{fll}_{\mathrm{ff}}$

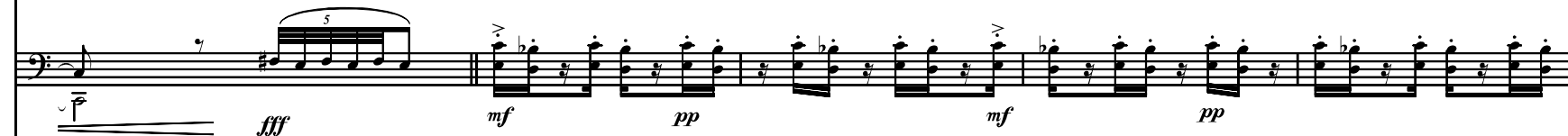

pn

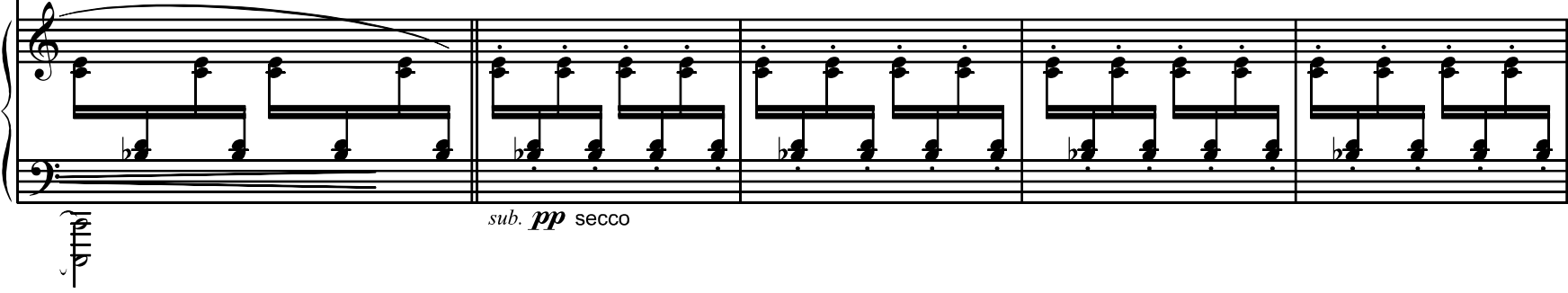

${ }^{25}$

${ }_{f}^{2}$

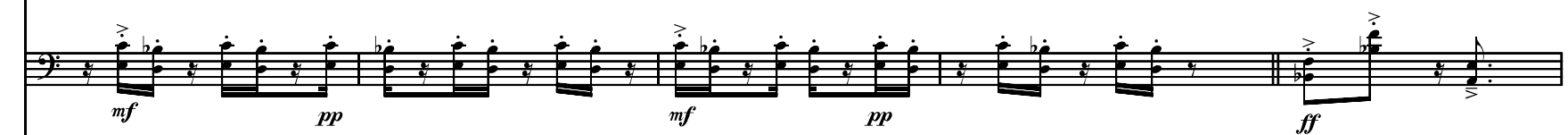

pn

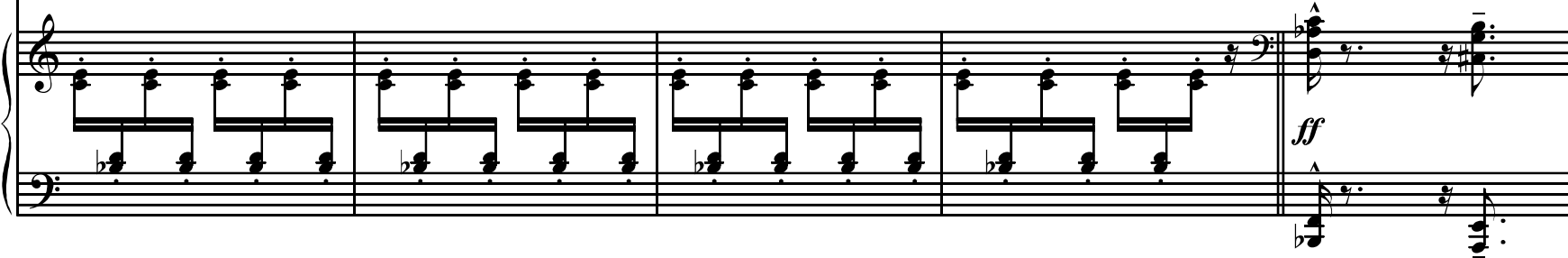




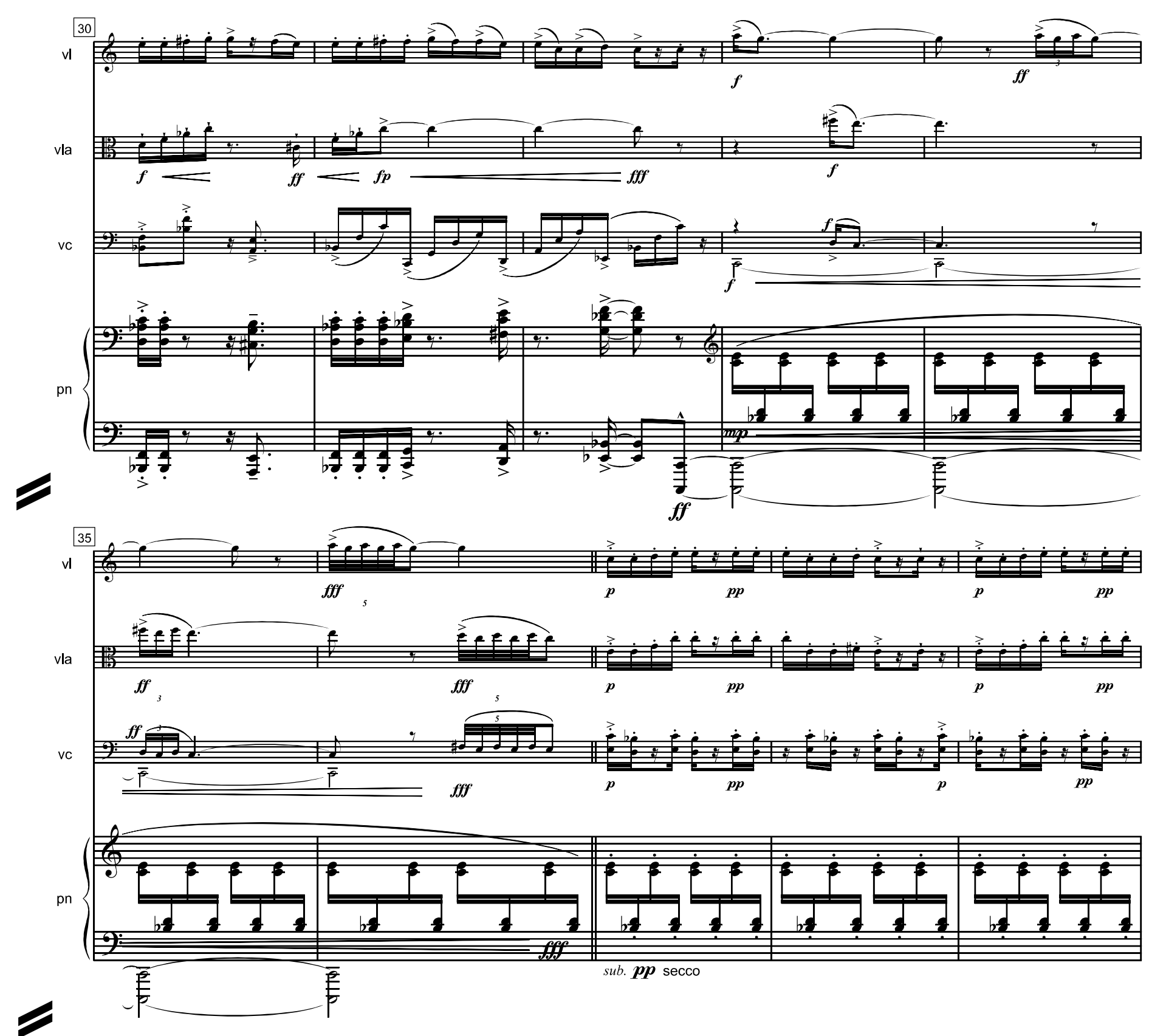

$\mathrm{VI}$

vla

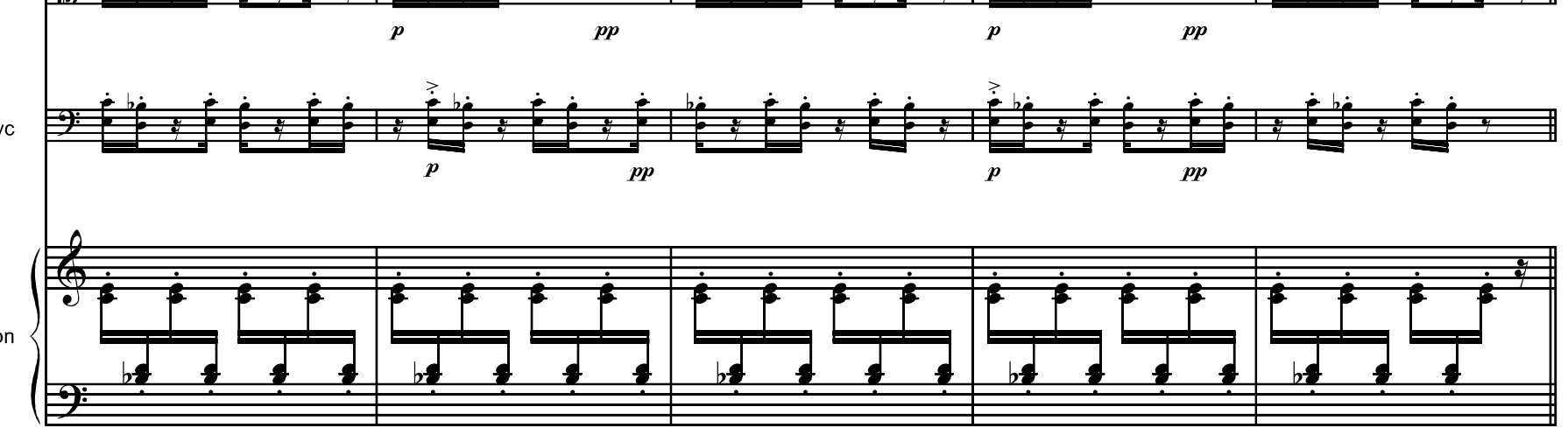


45

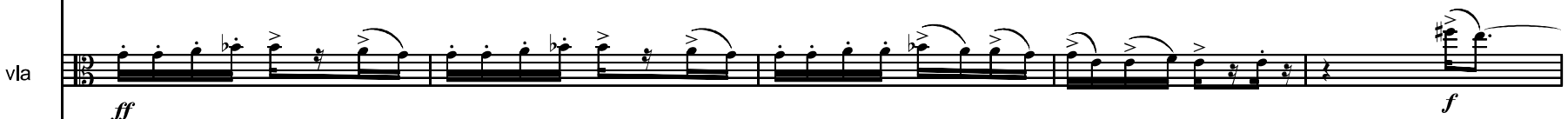

$v \mathrm{vc}$
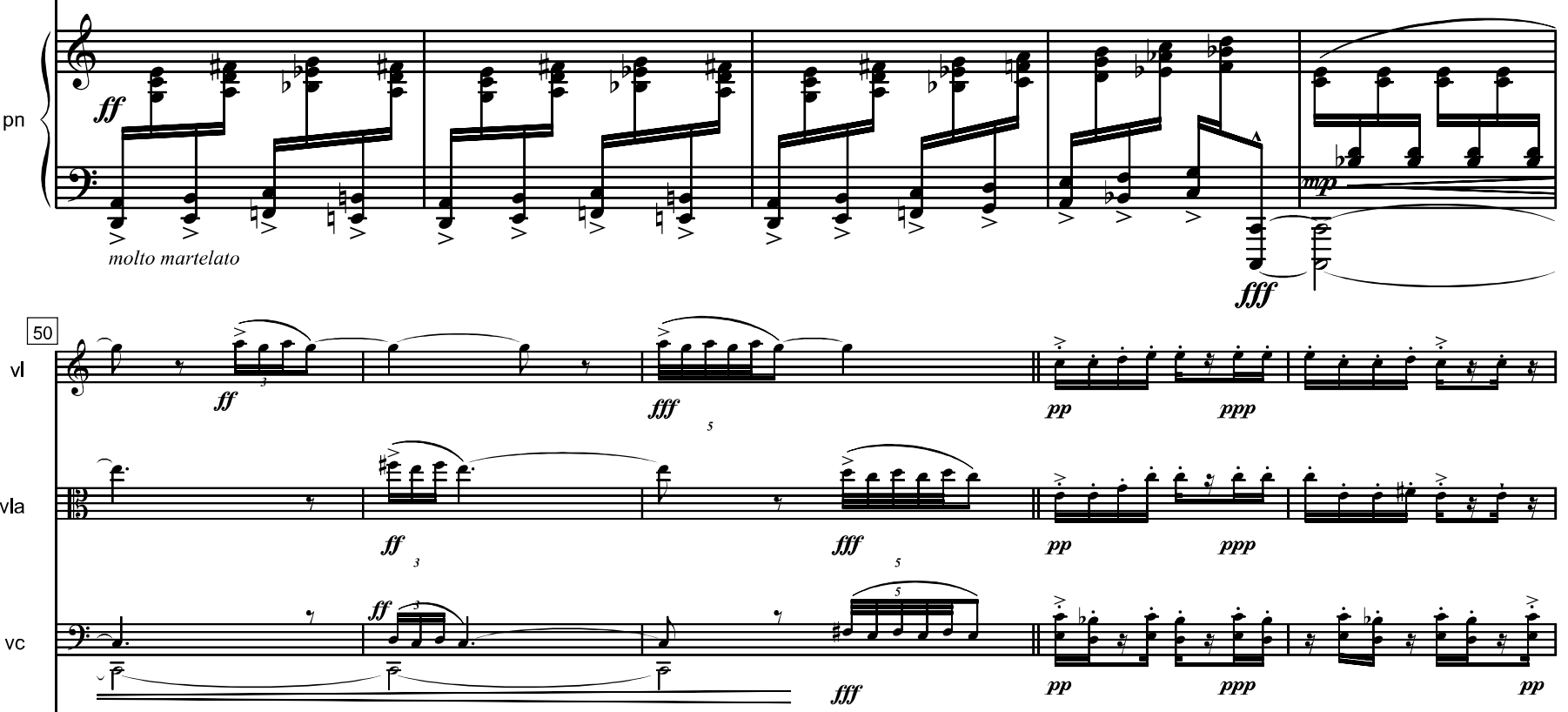

pn

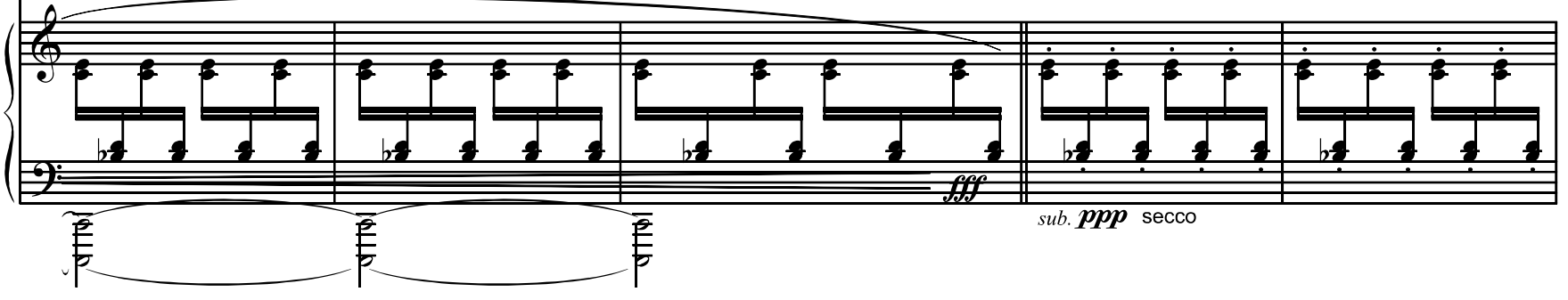

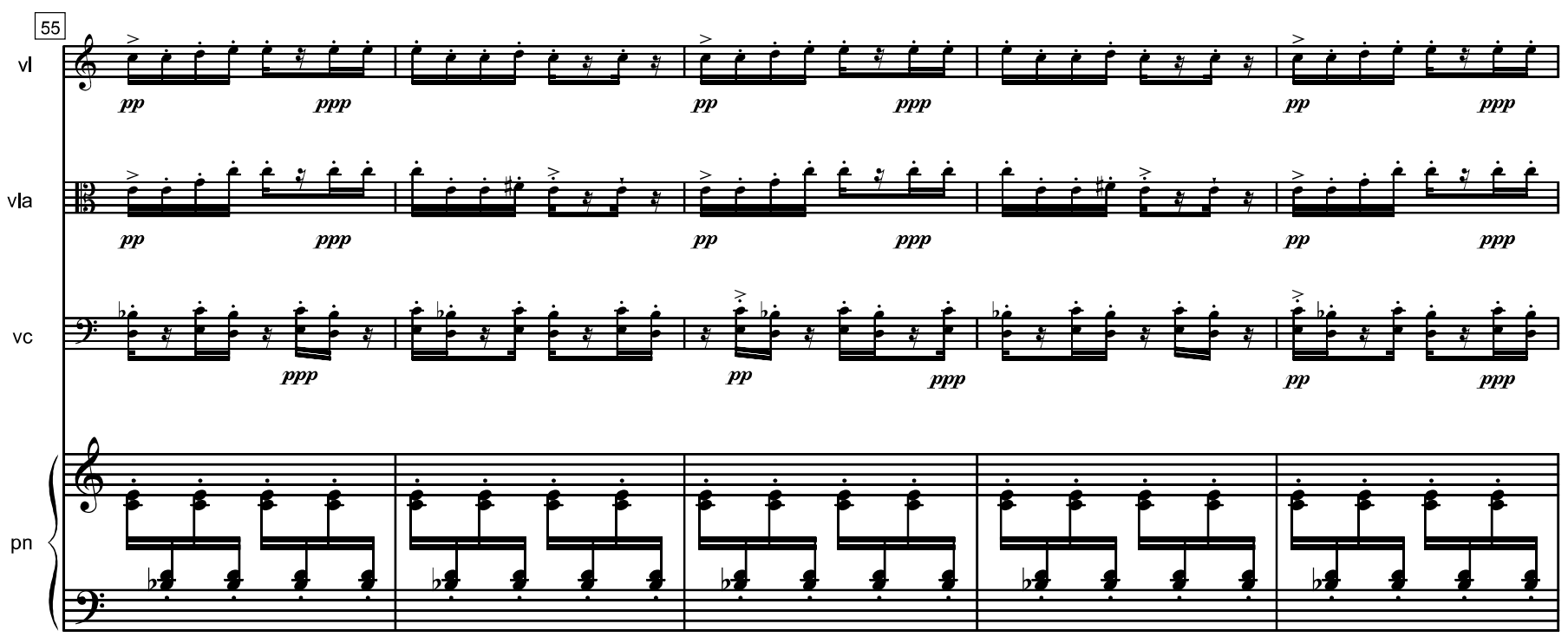


$60 \quad \bullet=30$ lentiss. sub.

V1

vla

(alce

vc

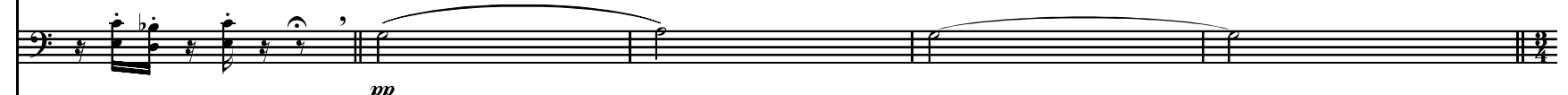
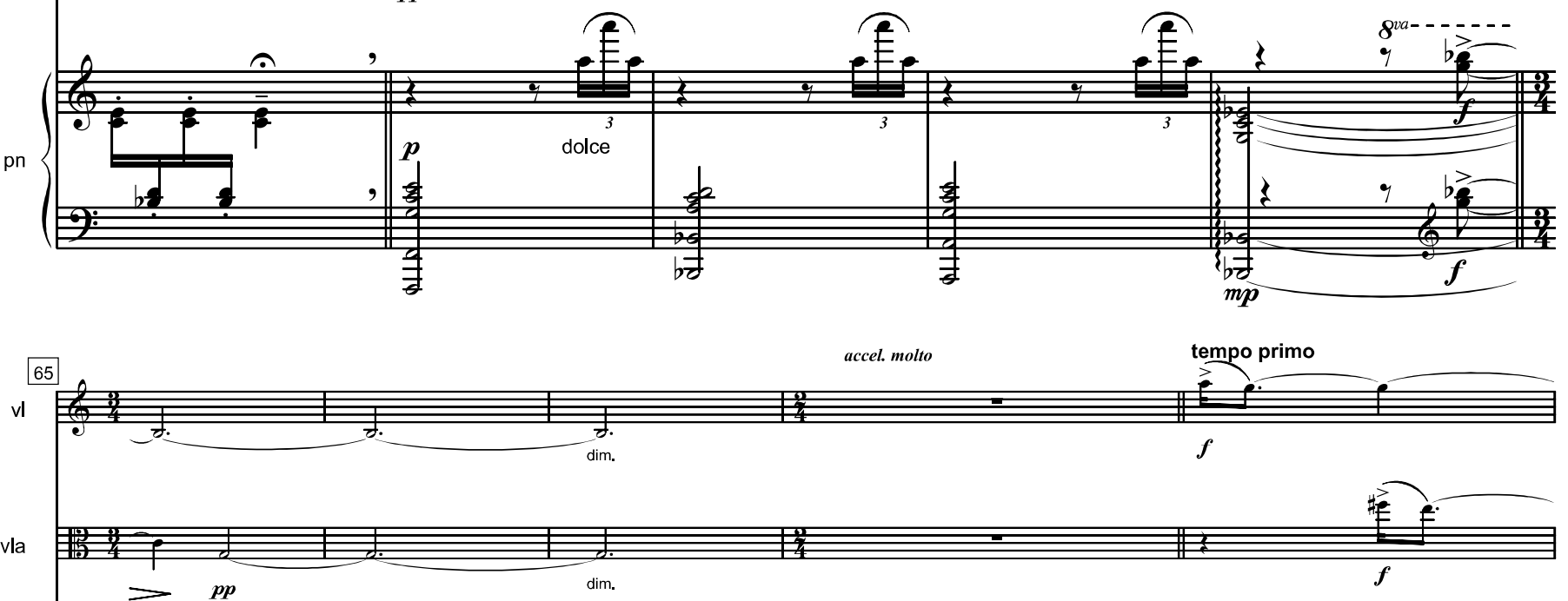

(2)

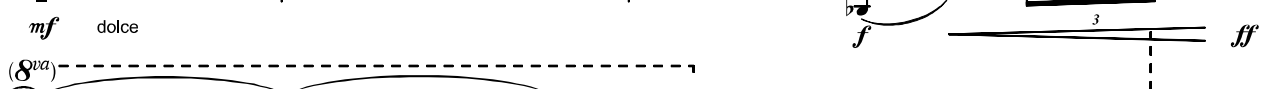
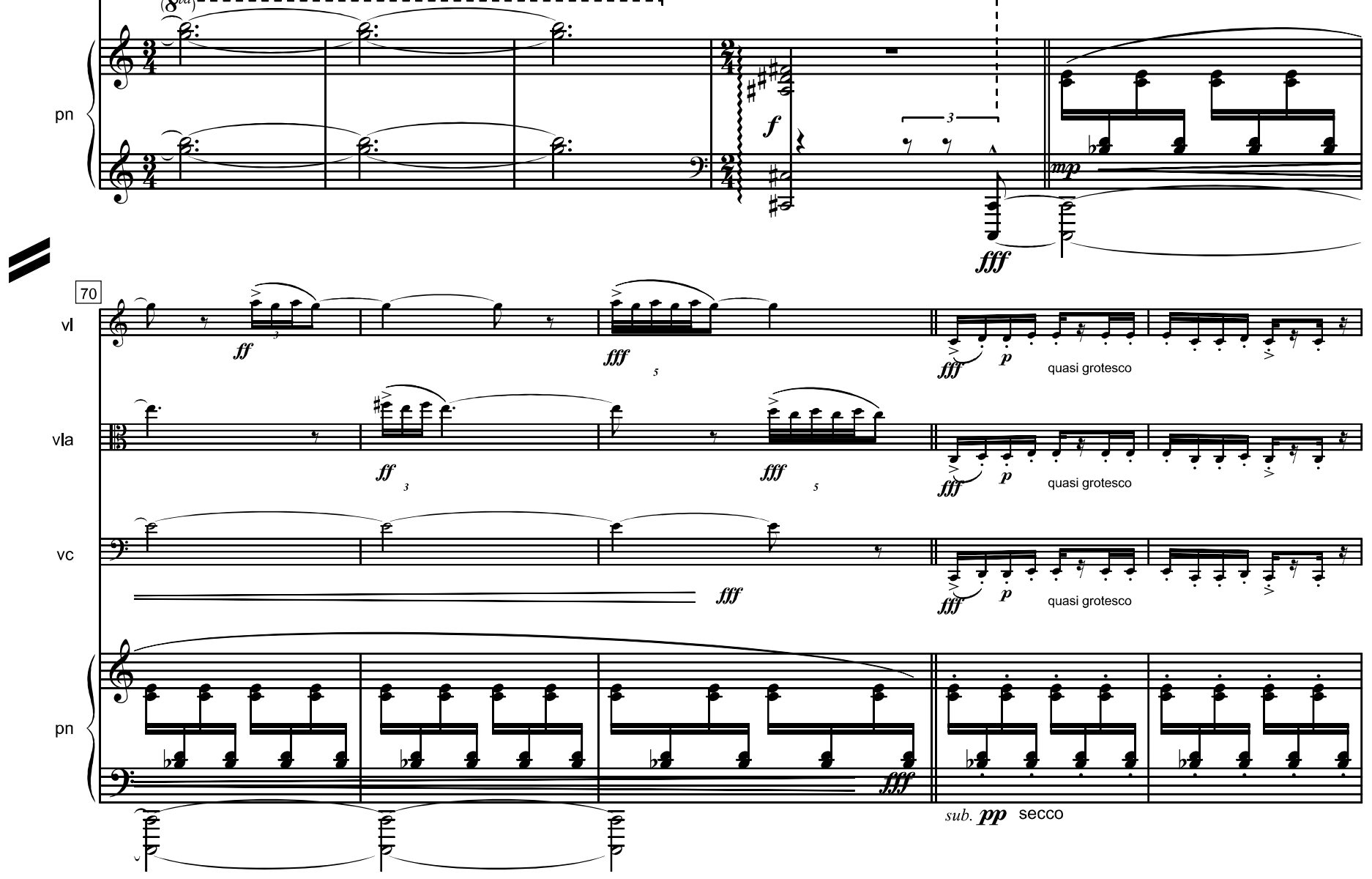
$\mathrm{VI}$

vla

$\underset{f f f f}{\frac{j}{p}}$

vc

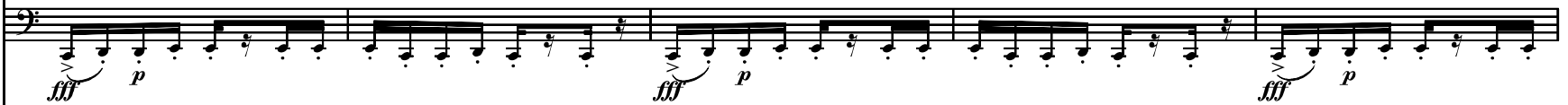

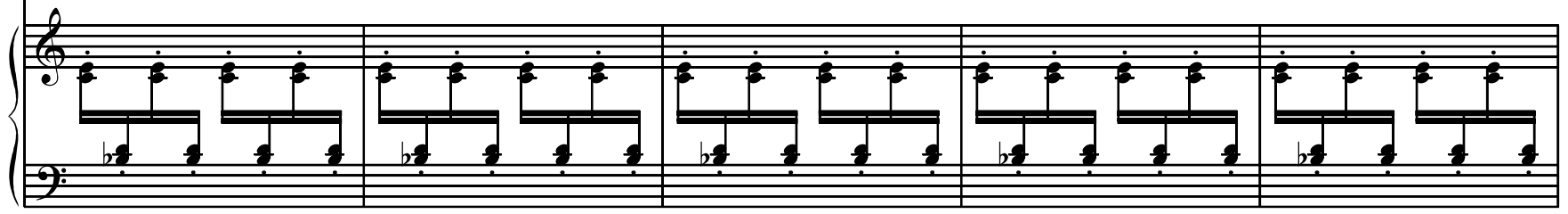

2
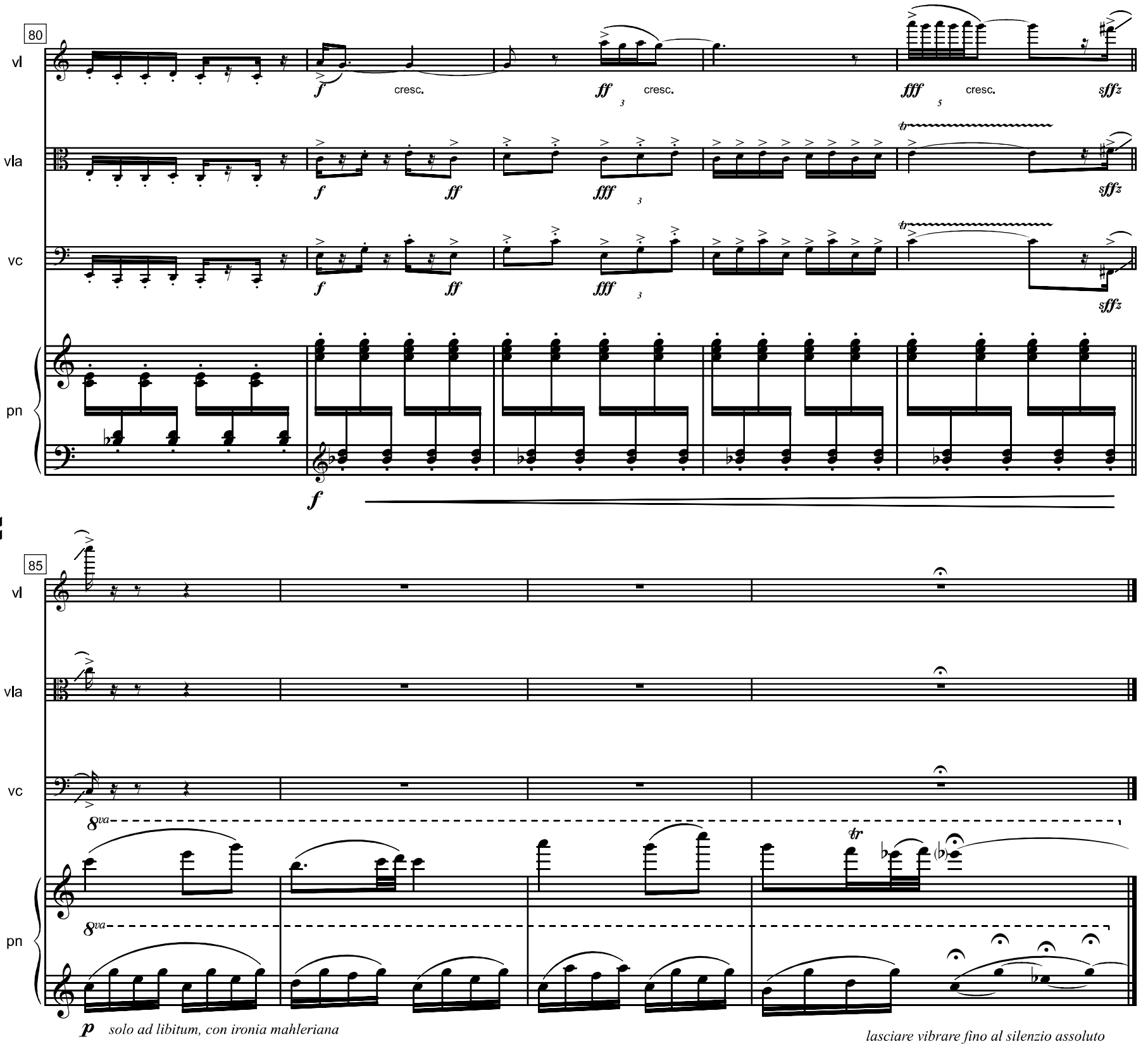